\title{
Developing inorganic carbon-based radiocarbon chronologies for Holocene lake sediments in arid NW China
}

Jiawu Zhang ${ }^{1}$, Xueyang $\mathrm{Ma}^{1}$, Mingrui Qiang ${ }^{1}$, Xiaozhong Huang ${ }^{1}$, Shuang $\mathrm{Li}^{1}$, Xiaoyan Guo $^{1}$, Andrew C. G. Henderson ${ }^{2}$, Jonathan A. Holmes ${ }^{3}$, Fahu Chen ${ }^{1}$

1. Key Laboratory of Western China's Environmental Systems (Ministry of Education), College of Earth and Environmental Sciences, Lanzhou University, Lanzhou, 730000, China 2. School of Geography, Politics and Sociology, Newcastle University, Newcastle upon Tyne, NE1 7RU, United Kingdom

3. Environmental Change Research Centre, Department of Geography, University College London, Pearson Building, Gower Street, London, WC1E 6BT, United Kingdom

*Corresponding author: jwzhang@1zu.edu.cn 


\section{Abstract}

Inorganic carbonates are often used to establish radiocarbon $\left({ }^{14} \mathrm{C}\right)$ chronologies for lake sediments when terrestrial plant remains (TPR) are rare or when bulk organic matter is insufficient for dating, a problem that is common for many lakes in arid regions. However, the reservoir effect (RE), as well as old carbon contributed from the lakes catchment make it difficult to establish reliable chronologies. Here we present a systematic study of inorganic ${ }^{14} \mathrm{C}$ ages of two lake-sediment sequences, one from a small-enclosed saline lake - Lake Gahai in Qaidam Basin, and the other from a large freshwater lake - Lake Bosten in Xinjiang. Modern dissolved inorganic carbon (DIC) of the lakes, paleo-lake sediments exposed in the catchment, and mollusk shells in core sediments from Lake Gahai were dated to assess the RE and the contribution of pre-aged carbon to the old ages in the cores. We propose a statistical regression to assess more than one RE for the ${ }^{14} \mathrm{C}$ carbonate ages within our sedimentary sequences. Old radiocarbon ages contributed by detrital carbonates were assessed by comparing the ages of mollusk shells with those of carbonates at the same sediment depths. We established the RE of the authigenic component and assessed detrital old carbon contributions to our two sites, and this was used to correct the ${ }^{14} \mathrm{C}$ ages. Based on this approach, we developed age models for both cores, and tested them using ${ }^{210} \mathrm{~Pb}$ ages in both cores and TPR-based ${ }^{14} \mathrm{C}$-ages recovered from Lake Bosten. We further tested our age models by comparing carbonate-based oxygen isotope $\left(\delta^{18} \mathrm{O}\right)$ records from both lakes to an independently-dated regional speleothem $\delta^{18} \mathrm{O}$ record. Our results suggest if sedimentary sequences are densely dated and the RE and the contribution of old carbon from detrital carbonates can be ascertained, robust chronological frameworks based on carbonate-based ${ }^{14} \mathrm{C}$ determinations can be established.

Key Words: Inorganic carbon, radiocarbon dating, lake sediments, reservoir effect, NW China

\section{Introduction}

Lacustrine sediments record valuable information about regional environmental changes and 
human impact during the late Quaternary, provided they are well dated (Yang et al., 2015). Radiocarbon $\left({ }^{14} \mathrm{C}\right)$ dating has long been one of the most frequently used dating techniques in establishing a reliable chronology for lake sediments spanning the $\sim 50,000$ years (Geyh et al., 1999). Terrestrial plant remains (TPR) are often the best material for ${ }^{14} \mathrm{C}$ dating in lake sediments because they use atmospheric carbon, and therefore contain no old carbon, provided they have not been reworked (Abbott and Stafford, 1996; Geyh et al., 1998, Oswald et al., 2005; Colman et al., 2009; Bertrand et al., 2012; Hou et al., 2012). Bulk or aquatic organic matter is often used for ${ }^{14} \mathrm{C}$ dating in the absence of suitable TPRs, although these can only be reliable if the 'reservoir effect' (RE) is properly assessed (Shen et al., 2005; Henderson et al., 2010; Mischke et al., 2010; Watanabe et al., 2010; Bertrand et al., 2012). Inorganic (calcium carbonate) carbon, including authigenic and biogenic carbonates have been used to date sediments that lack organic carbon, especially for lakes in arid regions, where the vegetation in the catchment is sparse or the aquatic productivity is limited due to high lake water salinity. The use of carbonate for ${ }^{14} \mathrm{C}$ dating materials often generates dates that are far older than the true ages (Fontes et al., 1996; Wu et al., 2010; Yang et al., 2010), because of the incorporation of old carbon into the samples from either the dissolved inorganic carbon (DIC) pool of the lake water (the RE for the authigenic component of the carbonate) or from catchment-derived carbonate (the detrital component of the carbonates). Accurate determination of the RE and the old detrital carbonate contribution is therefore essential to establishing an accurate and precise chronology using carbonate-based radiocarbon ages.

A number of studies have examined the $\mathrm{RE}$ on ${ }^{14} \mathrm{C}$ ages on bulk, aquatic organic matter and biological remains of aquatic organisms that feed on aquatic material, based on general comparative estimates (Hendy and Hall, 2006; Shishlina et al., 2007, 2012; Zhou et al., 2009; Olsen et al., 2010; Ascough et al., 2010, 2011; Wood et al., 2013; Zhao et al., 2013), calculations based on carbon (C) and nitrogen (N) isotopes (Lanting and van der Plicht, 1998; Cook et al., 2001; Watanabe et al., 2010; Bronk Ramsey et al., 2014), N/C ratios (Bertrand et al., 2012) or models (Soulet et al., 2011; Watanabe et al., 2013; Yu et al., 2007, 2014; Groot et 
al., 2014; Hart, 2014). However, as inorganic carbon is less frequently dated for radiocarbon estimates, the RE of inorganic carbon dates in lake sediments is not fully understood.

In previous studies of inorganic carbon-based dating, the RE has either not been corrected (Gasse et al., 1991) or been assumed to be constant and estimated either by regression of the dated ages versus the depth of sedimentary cores and then using the intercept on the age axis to represent the RE (Fontes et al., 1996), or by using the age of modern DIC samples (Hou et al., 2012). A chronology is then established by subtracting the intercept of the regression or the modern DIC ages from the radiocarbon age determinations. However, recent researches suggest that the RE may not be constant through time (e.g. Lake Sugan, Zhou et al., 2009; Lake Qinghai, Hou et al., 2012; An et al., 2012; Zhou et al., 2014; Lake Kusai, Liu et al., 2014; Lake Xingyun, Zhou et al., 2015). Thus, the RE of each dated sample remains an unresolved problem for dating both of organic and inorganic carbon, although several approaches to assessing RE have been developed (see Hou et al., 2012). We present a statistical regression method for assessing more than one $\mathrm{RE}$ for inorganic ${ }^{14} \mathrm{C}$ ages in one sedimentary sequence by using sediment cores from a saline lake, Lake Gahai in the Qaidam Basin, NE Tibetan Plateau and a freshwater lake, Lake Bosten in Xinjiang, NW China. We aim to use the ${ }^{14} \mathrm{C}$ ages from inorganic carbon to establish chronologies acceptable with this method for continuous Holocene lacustrine sedimentary sequences in arid NW China.

\section{Study sites}

We investigated two lakes that are located beyond the modern summer monsoon limit in arid NW China (Fig. 1a). One is Lake Gahai, a small-enclosed saline lake (surface area of the lake is $\sim 35 \mathrm{~km}^{2}$ ) located in the eastern corner of Qaidam Basin on the northern Tibetan Plateau (Fig. 1b) with no perennial rivers flowing into the lake. Groundwater appears as springs on the northwestern and eastern shores (Fig. 1b). The regional climate is arid with a mean annual precipitation of $c .160 \mathrm{~mm}$ and a potential evaporation of $c .2000 \mathrm{~mm} \cdot \mathrm{a}^{-1}$ (Zhao et al., 2008). Evaporation is the main mechanism of water loss from the lake resulting in high salinity of the lake water (ca. $91 \mathrm{~g} \cdot \mathrm{L}^{-1}$ ). The $\mathrm{pH}$ of the lake water is 8.28 (Chen et al., 2007), with major 
cations and anions of $\mathrm{Na}^{+}>\mathrm{K}^{+}>\mathrm{Mg}^{2+}>\mathrm{Ca}^{2+}$ and $\mathrm{Cl}^{-}>\mathrm{SO}_{4}{ }^{2-}>\mathrm{CO}_{3}{ }^{2-}>\mathrm{HCO}_{3}{ }^{-}$. There is a small area of wetland with grass and shrubs to the east of the lake, but vegetation around the lake is sparse and of desertic type (Zhao et al., 2008).

The lake productivity is low, organic matter content in the sediments is less than $3 \%$, and plant remains in the sediments are rare. ${ }^{210} \mathrm{~Pb}$ and ${ }^{137} \mathrm{Cs}$-dated short cores from Lake Gahai suggest a high sedimentation rate (the top $22 \mathrm{~cm}$ sediments covers the last 50 years at water depth of $6.4 \mathrm{~m}$ in northwest part of the lake, Zhao et al., 2008) and carbonate content, pollen and oxygen and carbon isotopes of ostracod shells suggest the lake is very sensitive to regional paleoclimate change over the late Holocene (Zhao et al., 2008; Li et al., 2012). Lake Gahai has long been a target for drilling with two long cores (DG02: $35 \mathrm{~m}$; DG03: $37 \mathrm{~m}$ ) drilled on the northern shore of Lake Gahai in 2003 proved to be of Holocene age, but the age control was poor due to lack of organic matter coupled with age reversals (Chen et al. 2007; Cao et al. 2009; Pan and Chen, 2010; He et al., 2014), indicating the difficulty of obtaining a chronology in such lakes in arid NW China.

Fig. 1

The other lake is Lake Bosten, a large freshwater lake located in the southeastern part of Yanqi Basin on the south slope of Tianshan Moutains in Xinjiang, NW China (Fig. 1c). It is the largest inland freshwater lake $\left(c .1000 \mathrm{~km}^{2}\right)$ in China. The lake is in an extremely arid region with mean annual precipitation of $70 \mathrm{~mm}$ and annual potential evaporation of $c .2000$ mm (Huang et al., 2009). The Kaidu River is the major river that recharges the lake in the west, accounting for more than $80 \%$ of the total water input. The lake water flows out of the lake through Peacock River (Fig.1c). The current salinity of the lake water is $1.8 \mathrm{~g} \cdot \mathrm{L}^{-1}$ and the $\mathrm{pH}$ of the lake water is 8.5. Similar to Lake Gahai, the organic matter content in the sediments is low (1 4\%, Wünnemann et al., 2003; Zhang et al., 2010) and terrestrial plant remains are rarely found in the cores. Previous research on sediment cores from this lake has generally employed dating using bulk organic matter or more rarely plant remains (Wünnemann et al., 
2003, 2006; Mischke and Wünnemann, 2006; Huang et al., 2009), leading to uncertainties in the resulting age models.

\section{Materials and Methods}

\subsection{Lake Gahai (Core GHB)}

A 14-m long core (GHB) was recovered in May 2008 using a UWITEC drilling platform at a water depth of $11.4 \mathrm{~m}$ in Lake Gahai (Fig. 1b). A sand layer at $14 \mathrm{~m}$ sediment depth terminated the drilling hole. The sediments above the sand layer are continuous and are greyish clay, with some silt to silty clay (Fig. 2a). The total organic carbon (TOC) in the sediment is lower than $3 \%$, therefore only 1 sample at $55.08 \mathrm{~cm}$ contained sufficient plant remains for ${ }^{14} \mathrm{C}$ dating. As a result, we selected 28 carbonates samples at approximately $50 \mathrm{~cm}$ intervals to ${ }^{14} \mathrm{C}$ date the inorganic carbon (Fig.2a). The selected samples were wet-sieved with deionized water through a 360-mesh sieve $(44 \mu \mathrm{m})$ and the fine fraction was used for AMS ${ }^{14} \mathrm{C}$ dating. 17 fine-grained samples were measured in the $\mathrm{AMS}{ }^{14} \mathrm{C}$ lab of Peking University, China and the other 11 samples, together with one sample of plant remains, were dated at Beta Analytic Inc., USA. Mollusk shells found in four of the samples (Fig. 2a) were also dated at Beta Analytic Inc. Both laboratories use the standard AMS ${ }^{14} \mathrm{C}$ dating procedures for dating of carbonate sediments. The conventional half-life of 5568 -year is used when calculating ${ }^{14} \mathrm{C}$ ages with the measured percent modern carbon (pMC) value of each sample (Table 1).

Samples of the total dissolved inorganic carbon (DIC) of the lake water were collected from Lake Gahai and two other lakes (Toson and Hurleg) in the catchment (Table 2 and Fig. 3). DIC was precipitated on site as $\mathrm{BaCO}_{3}$ by adding $15 \mathrm{ml}$ of saturated $\mathrm{Ba}(\mathrm{OH})_{2}$ solution to 85 $\mathrm{ml}$ of surface water following the method of Kusakabe (2001). Precipitated $\mathrm{BaCO}_{3}$ from the water samples was filtered using cellulose nitrate filter papers, washed several times with deionized water and then transferred into glass vials and sealed in the field before drying in the lab. In addition, samples taken from exposed paleolake sediments on the northwest shore of the lake were used to assess the potential contribution of detrital carbonates to the radiocarbon age of the sediment core (Table 2 and Fig. 3). Three surface horizon $(<1 \mathrm{~cm}$ deep) 
samples were collected, and the fine-grained fraction prepared using the same method for the core samples as described above. 12 DIC samples and three surface paleolake sediment samples were also dated at Beta Analytic Inc., USA. A short core (GHC1) taken in 2010 near the GHB core site was dated using ${ }^{210} \mathrm{~Pb}$, and we used the ${ }^{210} \mathrm{~Pb}$-based age model (Supplementary Fig. S1) to test our DIC-based chronology in the most recent part of GHB.

\subsection{Lake Bosten (Core BST04H)}

The BST04H core was recovered from Lake Bosten (Fig. 1c) using a Livingstone corer in 2004. The total length of BST04H is $625 \mathrm{~cm}$, and sand appears from $550 \mathrm{~cm}$ to the base. The upper $550 \mathrm{~cm}$ of the core is mainly greyish clay (Fig. 2b), and even though some of the results of this core have been previously published (Huang et al., 2009), the chronological control remains poor because terrestrial plant remains are rare, with only several age points constraining the last 8000 years of the sequence. Therefore we use inorganic carbon dating to improve its chronology and test the validity of our RE correction method in freshwater lakes.

Inorganic carbon samples were selected at approximately 20 -cm intervals for the upper 200 $\mathrm{cm}$ and at c. 50-cm intervals for the rest of the core (Fig. 2b). The top $20 \mathrm{~cm}$ of the core was disturbed during the coring in the field and therefore was replaced by the top $20 \mathrm{~cm}$ of another

parallel core (BST04C, Chen et al., 2006), which has been dated using ${ }^{210} \mathrm{~Pb}$ (Supplementary Fig. S1). 18 samples were selected and processed using the same procedure as described above for Lake Gahai, and inorganic radiocarbon samples for core BST04H were dated at Beta Analytical Inc.

Fig. 2

For both cores, the measured pMC values were corrected with their respective $\delta^{13} \mathrm{C}$ values to get the corrected ${ }^{14} \mathrm{C}$ ages (Table 1 ). In the pMC correction, we use the equation proposed by Stuiver and Robinson (1974) for more precise calculations to reduce the error in corrected ${ }^{14} \mathrm{C}$ ages: 


$$
A_{S N}=A_{S} 0.975^{2} /\left(1+\delta^{13} C / 1000\right)^{2}
$$

where $A_{S N}$ is the corrected pMC values and $A_{S}$ is the measured pMC values (Stuiver and Polach, 1977). Corrected ages were then assessed for RE derived from old carbon in DIC and detrital carbonate from old sediments in the catchment (dated age - RE/detrital age). After the $\mathrm{RE}$ and old carbon were assessed, the dates were finally calibrated for calendar ages before establishing the chronology of the sedimentary sequences. The calibration for calendar ages was undertaken using IntCal13 (northern hemisphere, Reimer et al., 2013) in the newly developed R-based package, Bacon (Christen and Pérez, 2010; Blaauw and Christen, 2011; also see the Bacon manual distributed with the software package), which uses a Bayesian approach to provide the calendar ages of each depth (Dee and Bronk Ramsey, 2014), similar to the depositional model in OxCal (Bronk Ramsey, 2008; Bronk Ramsey and Lee, 2013). As this paper focuses on the methodology of how to establish a chronology with inorganic carbon dating, the detailed procedures of RE/old detrital carbon assessment and the parameters used in Bacon are described in Section 5.

\section{Results}

\subsection{Ages of inorganic carbon in cores}

The top sample of GHB $(1.15 \mathrm{~cm})$ was dated to $4536 \pm 35{ }^{14} \mathrm{C}$ yr BP (Table 1), and we use ${ }^{14} \mathrm{C}$ yr BP for ${ }^{14} \mathrm{C}$ ages and $\mathrm{Cal}$ a BP or Cal ka BP for calendar ages in this paper, $1 \mathrm{a}=1$ year, $1 \mathrm{ka}=1000$ a, BP = before present, $\mathrm{P}=1950$ A.D. (Millard, 2014). Mischke et al. (2013) suggested if surface sediments are taken after 1950 A.D., then the influence of nuclear bomb testing should be considered in assessing the modern RE. The GHB core was taken in 2008, and the ${ }^{210} \mathrm{~Pb}$ profile of the short core nearby (Supplementary Fig. S1; Table S1) suggests a sedimentation rate of ca. $3 \mathrm{~mm} \cdot \mathrm{a}^{-1}$ for the top few centimeters. Therefore, the top $1 \mathrm{~cm}$ of GHB core covers sediments from 2006 to 2008 A.D. According to the extension curve of modern ${ }^{14} \mathrm{C}$ fraction curve $\left(\mathrm{F}^{14} \mathrm{C}\right)$ published by Levin et al. (2008), the mean $\mathrm{F}^{14} \mathrm{C}$ value between 2006 and 2008 A.D. is $106.02 \%$. When the estimated $\mathrm{F}^{14} \mathrm{C}$ value of $106.02 \%$ was 
used for the atmospheric $\mathrm{CO}_{2}$ in 2006-2008, the calculated age of the top sample became $5005{ }^{14} \mathrm{C}$ yr BP, nearly $500{ }^{14} \mathrm{C}$ years older than the dated age. As the surface sample was not dated in BST04H core, this post-bomb effect cannot be assessed.

In the BST04H core, the sample at $20.5 \mathrm{~cm}$ was dated to $2688 \pm 30{ }^{14} \mathrm{C} \mathrm{yr}$ BP. The apparent top age of $\mathrm{GHB}$ (either $4536{ }^{14} \mathrm{C}$ yr BP or $5005{ }^{14} \mathrm{C}$ yr BP if the post-bomb effect is considered) and that of $20.5 \mathrm{~cm}$ in BST04H $\left(2688{ }^{14} \mathrm{C} \mathrm{yr} \mathrm{BP}\right)$ are not the age of modern or recent sediments, suggesting that there are significant REs for inorganic carbon in both lakes. For other ages at lower depths, although most are generally in stratigraphic order, some of them are reversed (Table 1), suggesting older carbon is included in the samples.

The ages of mollusk shells from four depth intervals from core GHB at $606.03 \mathrm{~cm}, 1058.85$ $\mathrm{cm}, 1125.56 \mathrm{~cm}$ and $1224.44 \mathrm{~cm}$ were dated to $8231 \pm 40,11768 \pm 50,12275 \pm 50$ and 13489 $\pm 50{ }^{14} \mathrm{C}$ yr BP, respectively. However, the inorganic carbonate samples at the same depths were dated to $12049 \pm 50,13720 \pm 50,15297 \pm 55$ and $20611 \pm 90{ }^{14} \mathrm{C}$ yr BP, displaying much older ages than the shells at the same depths (Table 1), indicating these samples include pre-aged carbonates older than the shells.

\section{Table 1}

\subsection{Ages of modern water DIC and surface sediments in Lake Gahai catchment}

Fig. 3 shows the location and ages of water DIC and paleolake sediments in the catchment of Lake Gahai (also see Table 2). The ages of water DIC decreases from $2140 \pm 30{ }^{14} \mathrm{C} \mathrm{yr} \mathrm{BP}$ in the Bayin River to the south of Delingha City to $1190 \pm 30{ }^{14} \mathrm{C}$ yr BP in Lake Hurleg (which is open), $1060 \pm 30{ }^{14} \mathrm{C}$ yr BP in Bayin River between Lake Hurleg and Lake Toson, and to $-183 \pm 40{ }^{14} \mathrm{C}$ yr BP $(\mathrm{pMC}=102.3 \pm 0.5$, the DIC sample was taken in 2011) in southeast corner of Lake Toson. Similarly, in Lake Gahai, a spring water (groundwater) flowing into the lake at the northwest corner gives a DIC age of $5620 \pm 30{ }^{14} \mathrm{C} \mathrm{yr} \mathrm{BP}$, other water samples from the lake give DIC ages much younger than the spring sample, varying from $1550 \pm 30$ to 
$240 \pm 30{ }^{14} \mathrm{C}$ yr BP. Two samples of a very small spring to the east of the lake were dated to $100 \pm 30$ and $600 \pm 30{ }^{14} \mathrm{C}$ yr BP. One water sample from a well (groundwater) several hundred meters to the west of Lake Gahai gives a DIC age of $6280 \pm 30{ }^{14} \mathrm{C} \mathrm{yr} \mathrm{BP}$, but the water of the well was observed to be stagnant, and therefore may not be recharging Lake Gahai at present or charges the lake at a very slow rate.

The three surface paleolake sediment samples to the northwest of Lake Gahai give very old ages between $14550 \pm 50$ and $16690 \pm 60{ }^{14} \mathrm{C}$ yr BP (Fig. 3 and Table 2). They are exposed paleolake sediments deposited when the lake level was higher than the present (Fan et al., 2010). These old carbonate ages have the potential to provide information for ages in the core (discussed in Section 5.3.).

Fig. 3

Table 2

\section{Processes for establishing an age model using inorganic carbon ages}

\subsection{Preliminary RE assessment for the inorganic carbon ages}

In lake sediments that are not annually laminated, one way of assessing the RE is by determining the age of modern water DIC or of the surface sediment sample and using this as the RE for the dated sequence (e.g. Hou et al., 2012). In Lake Gahai, the age of the modern lake water DIC (section 4.2., Fig. 3) suggests they are site-specific and decrease rapidly at sites further away from the source of old DIC (e.g. groundwater $=5620 \pm 30{ }^{14} \mathrm{C} \mathrm{yr} \mathrm{BP}$ ). As the GHB core was recovered from the northern part of the lake, close to the source of groundwater, we can expect a DIC age $<5620{ }^{14} \mathrm{C}$ yr BP, however we cannot determine an exact age since we don't have a measurement of modern water DIC at this location. Therefore, it is unrealistic to use the modern DIC age as the RE for the GHB core. In addition, the surface sediment sample is influenced by post-bomb effects, and therefore the age of $4536 \pm$ $35{ }^{14} \mathrm{C}$ yr BP only represents the minimum value for the modern $\mathrm{RE}$ at the coring site 
(Mischke et al., 2013). Even if we correct our radiocarbon ages taking into account post-bomb effects, the retraction of $5005{ }^{14} \mathrm{C}$ yr BP does not resolve the age reversal problem for core GHB. This would suggest that applying a constant RE to all dates is unrealistic for Lake Gahai. In Lake Bosten, there is no age determination for surface sediments or lake water DIC, and therefore we cannot assess its modern RE. In order to assess RE across these two cores, and to draw comparisons between them in terms of changing RE we use an 'intercept method' (Hou et al., 2012) using inorganic ages that are in stratigraphic order.

The 'intercept method' has been employed at many carbonate-rich sites on the Tibetan Plateau. It is based on the linear relationship between ${ }^{14} \mathrm{C}$ ages and depth, and is defined by the following regression equation:

$A=a \times D+b$

where $\mathrm{A}=$ age, $\mathrm{D}=$ depth in core, $a$ is the slope and $b$ is the intercept of the regression. As a result, the intercept $b$ on the age axis is then regarded as the $\mathrm{RE}$ for the ${ }^{14} \mathrm{C}$ ages included in the linear regression (Fontes et. al., 1996; Shen et. al., 2005; Henderson and Holmes, 2009; Henderson et al., 2010; Wu et al., 2006, 2010; Kramer et al., 2010; An et al., 2012; Zhou et al., 2014). This method, however, assumes a constant sedimentation rate and a relatively stable RE through time so that the linear relationship can be assumed. Hou et al. (2012) pointed out that such an assumption is unlikely valid for most lakes. Therefore, we need to consider improved ways of using the 'intercept method' by assuming a similar RE during periods with similar hydrological conditions for a continuous sedimentary sequence whose sedimentary rate changes, thus the regression is not limited to linear type. In practice, however, different intercepts are obtained if different dating points are included in the regression, resulting in many possible estimates for a lake's RE and determining the most accurate one is non-trivial, especially when no TPR or varve ages are available for reference. In order to avoid such randomness, preliminary regressions should be tried based on careful observations on the general age-depth distributions and lithological changes before a regression model is fixed for 
assessing the RE. The following steps are generally needed:

1) Exclude the apparently reversed extremely old ages along the depth of the core and keep the remaining ages that are generally in stratigraphic order. Slightly reversed ages could be included for preliminary regressions;

2) Make preliminary regressions from linear type with equation (2) to a quadratic type defined as:

$A=a \times D^{2}+b \times D+c$

where $\mathrm{A}=$ age, $\mathrm{D}=$ depth in core, $a$ is the quadratic term ratio, $b$ is the coefficient on $\mathrm{D}$, and $c$ is the intercept. Compare these two types of regression and determine which equation gives higher correlation (represented by the $r^{2}$ values). Select the type of regression with higher $r^{2}$ values as it should describe the age-depth relationship better (Colman et al., 2009);

3) Refine the regression on the basis of the preliminary one to make sure the intercept of the refined regression could be used for RE assessment.

In core GHB from Lake Gahai, when 13 extremely old ages are excluded, there are 19 ages that fall in stratigraphic order (shown in Supplementary Fig. S2). The linear equation for these data gives an intercept of $4066 \pm 193{ }^{14} \mathrm{C}$ years, which is smaller than the minimum modern RE represented by the core top sediment $\left(4536{ }^{14} \mathrm{C}\right.$ yr BP) suggesting it is not suitable to be used as the RE for the whole core. In addition, the quadratic relationship between these dates gives a higher $\mathrm{r}^{2}$ value than the linear equation. According to this preliminary regression $\left(\mathrm{A}_{0}\right.$ in Fig. 4a, $\left.\mathrm{n}=19, \mathrm{r}^{2}=0.9764\right)$, there is an intercept of $4764 \pm 243{ }^{14} \mathrm{C} \mathrm{yr}$ BP. As demonstrated in Lake Gahai, the modern water DIC ages in the watershed can be used to assess if such preliminary regressions give reasonable RE values. Results in Fig. 3 suggest the ages of lake water DIC are highly variable, decreasing rapidly with increasing distance from the old DIC 
water source at the northwest corner. The GHB core is in the northern part of the lake close to the old DIC source, suggesting the averaged RE for the carbonates in the sediment at the core site should be larger than other sites in the lake and smaller than the input groundwater DIC age $\left(5620 \pm 30{ }^{14} \mathrm{C}\right.$ years $)$. The range of our proposed offset is $4764 \pm 243{ }^{14} \mathrm{C}$ years, less than that of groundwater DIC, indicating the regression-based assessment of the average RE for GHB is realistic.

In core BST04H from Lake Bosten, we undertook a similar process to GHB core for a suitable regression by excluding 6 old ages and 2 younger ages after 4 pairs of regression and comparison (Supplementary Fig. S3a to S3h). Indeed, there are many possibilities for the intercepts for RE assessments as the older and younger ages were included. We identified the older ages after each pair of regression (lying out of the $95 \%$ confidence line) and excluded the two younger ages at $20.5 \mathrm{~cm}\left(2688 \pm 30{ }^{14} \mathrm{C} \mathrm{yr} \mathrm{BP}\right)$ and $550.2 \mathrm{~cm}\left(9755 \pm 40{ }^{14} \mathrm{C} \mathrm{yr} \mathrm{BP}\right)$ as they also lie outside of the $95 \%$ confidence line (Fig. 4b). The regression with the highest $\mathrm{r}^{2}$ values for the $\mathrm{RE}$ assessment ( $\mathrm{A}_{0}$ in Fig. $4 \mathrm{~b}, \mathrm{n}=10, \mathrm{r}^{2}=0.9871$ ) was selected, with an intercept of $3398 \pm 182{ }^{14} \mathrm{C}$ yr BP. In this lake, although modern water DIC was not dated, we compared the intercept from our preliminary regression with the TPR age at a similar depth to make sure the average RE for the core is reasonable. For example, the carbonate age at 399.9 $\mathrm{cm}$ is $8218 \pm 40{ }^{14} \mathrm{C}$ yr BP, and the closest TPR age at $396 \mathrm{~cm}$ is $4740 \pm 40{ }^{14} \mathrm{C}$ yr BP (Table 1). The offset between the carbonate age and the TPR age is $3478{ }^{14} \mathrm{C}$ years, a little larger than the intercept of $c .3400{ }^{14} \mathrm{C} \mathrm{yr} \mathrm{BP}$ (Fig. 4b), indicating our preliminarily assessed average RE of c. $3400{ }^{14} \mathrm{C}$ yr BP for BST04H is also acceptable.

Fig. 4

\subsection{Refining radiocarbon age-depth relationships}

Even after these preliminary regressions (Fig. 4) it is evident there are still some age reversals in the age-depth profiles, especially in core GHB (Fig. 4a). This means if one constant RE is applied to the whole sequence, these ages are still not in stratigraphic order. In order to refine 
these initial regressions we need to test whether more than one RE is applicable for the sequence. In Fig. 4a, the younger and older ages lie to both sides of the preliminary regression line, indicating they may contain different REs. If we consider separating them into younger and older groups and undertake regression analysis for each group independently, four age points lie to the left of the preliminary regression line and define a 'younger' group (defined as $A_{1}$ ) and the others define an 'older' group (defined as $A_{2}$ ) of ages. Independent regression of these two groups show the coefficients $\left(a_{1}\right.$ and $\left.b_{1}\right)$ do not change significantly (Fig. 5a) compared to the preliminary $a$ and $b$ in the age-depth relationship in Fig. 4a. For example, the quadratic term ratios $\left(a_{1}\right.$ and $\left.a_{2}\right)$ are the same as the $a(0.0024)$ in Fig. 4a. The $b_{1}$ and $b_{2}(\sim 3.7)$ are slightly smaller than the $b$ in Fig. $4 \mathrm{a}(\sim 4.2)$. However, the correlation coefficient $\left(\mathrm{r}^{2}\right)$ increases, resulting in an overall age-depth relationship of the refined regressions nearly parallel to the preliminary regression (as in Fig. 4a). Therefore, the age-depth relationships are not changed significantly, but there are two new intercepts for core GHB representing different REs within a single lake. In core BST04H, based on the preliminary regression in Fig. $4 \mathrm{~b}$, there is only one younger age $\left(122.3 \mathrm{~cm}\right.$ : $\left.3840 \pm 30{ }^{14} \mathrm{C} \mathrm{yr} \mathrm{BP}\right)$ to the left side of the preliminary regression line (Fig. 5b). The refined quadratic term and the intercept change slightly but the regression line is parallel to the initial preliminary regression (as in Fig. 4b). However, the $\mathrm{r}^{2}$ value increases to 0.99 and the intercept value changes to $3464 \pm 141{ }^{14} \mathrm{C}$ years closer to the offset $\left(3478{ }^{14} \mathrm{C}\right.$ years $)$ between the carbonate age at $399.9 \mathrm{~cm}$ and the TPR age at $396 \mathrm{~cm}$, indicating an improvement on the preliminary regression.

Based on the refined regressions for GHB core (Fig. 5a), the two intercepts are $4522 \pm 64$ and $5128 \pm 154{ }^{14} \mathrm{C}$ years. This supports the notion that old groundwater DIC with an age of 5620 $\pm 30{ }^{14} \mathrm{C}$ years is 'diluted' to younger DIC with an age between $c .5130$ and $4520{ }^{14} \mathrm{C}$ years at the coring site; this approximates to the preliminary estimate described above $\left(4760 \frac{+360}{-240}\right.$ years $)$. Therefore, our estimated RE of $4522{ }^{14} \mathrm{C}$ years for the younger ages and $5128{ }^{14} \mathrm{C}$ years for the older ages down core are reasonable. In BST04H, as the younger group only includes 3 points, we could only obtain a refined $A_{l}$ equation (Fig. 5b). However, the intercept (3464 \pm 141 ) is closer to the offset of 3478 compared above. This lends confidence to the refined 
equation for BST04H describing the age-depth relationship and we therefore use $3464{ }^{14} \mathrm{C}$ years as the RE for ages included in the regression.

When the refined values for the RE are applied to individual dates, the chronology can usually be established with enough dating points to establish a densely dated sediment sequence. For example, we obtained 17 radiocarbon ages for GHB and 9 for BST04H (Fig. 5). However, the excluded ages (see triangles in Fig. 5) are consistently very old in some stages making the usable ages (i.e. those included in the age model) unevenly distributed down core. As a consequence lower parts of the core lack dating control, and increase chronological uncertainty if they are included in the age model. This problem relates to the assessment of the old carbon component of these apparently older ages (in both cores) or younger ones (in BST04H) that cannot be constrained using this regression approach.

\section{Fig. 5}

\subsection{Utilizing anomalously old or young dates in age models}

In most studies, outliers in an age-depth relationship are usually discarded because there is no obvious means by which to assess the RE or old carbon of such very old ages (e.g. Zhang and Mischke, 2009; An et al., 2012). However, if there is no evidence for hiatuses or sharp transitions in lithology that might lead to changes in sedimentation rate, these older ages may provide useful information on environmental changes within the lake or its catchment. For inorganic carbon dating, we consider the source material of the carbonates. If the carbonates are precipitated from the water column (authigenic or autochthonous carbonates) using water DIC, the old ages are likely to be caused by increased input of old DIC from old sediments or rocks in the catchment during wet periods when older carbonates are dissolved. If parts of the carbonate are from detrital input by river water or winds in arid regions (where allochthonous carbonates input is common), then the old ages are caused by the pre-aged detrital component.

The four mollusk shells dated from core GHB in Lake Gahai (red filled circles in Fig. 5a) can 
provide a basic framework for assessing whether these old ages were washed on to the coring site. As mollusk shells are secreted using DIC from the lake water (for shallow lakes that are not stratified we do not consider the difference between surface and bottom water as significant because the water mixes well in such shallow lakes), they should provide similar ages to those of authigenic carbonates. Indeed, the shell ages lie along the regression line of those dated using fine-grained carbonates (Fig. 5a). This suggests: 1) the shells were preserved in situ after death and their ages are representative those of the authigenic carbonates; and 2) these extremely old ages are caused by detrital input of pre-aged allochthonous carbonates. The offset between the shell ages and the old carbonate ages is then regarded as the radiocarbon contribution by detrital carbonates. This can provide an analogue for other reversed old ages. As the shell ages are lying along the $A_{2}$ regression line (Fig. 5a), the offset between each old age and the $A_{2}$ line represents the part contributed by detrital component, which can be determined by:

$A_{\text {detr }}=A-A_{2}$

where $A_{d e t r}$ is the estimated contribution by the detrital carbonate component, $A$ is ${ }^{14} \mathrm{C}$ ages, $A_{2}$ is the regression line determined by equation (3).

In order to check if such analogues are reasonable, we plot the estimated contribution from detrital carbonates $\left(A_{\text {detr }}\right)$ with carbonate content of each dated sample in Fig. 6a. Results suggest that $A_{\text {detr }}$ decreases with increasing carbonate content when the latter is less than $36 \%$ in Lake Gahai (Fig. 6a). When carbonate content continues to increase (greater than 36\%), $A_{\text {detr }}$ increases again $\left(\mathrm{n}=14, \mathrm{r}^{2}=0.9\right)$. Such a distribution means the proportion of detrital carbonate could be brought into the lake either by inflowing water during wetter periods (lower carbonate content) or by wind during drier periods (higher carbonate content, Fig. 6a). During the wet periods when smaller amount of authigenic carbonates precipitated from the lake water, detrital components washed in account for larger proportions in the total carbonate content, leading to larger contribution of the old ages. During dry periods, however, detrital 
components blown in can also contribute several thousand ${ }^{14} \mathrm{C}$ yrs to the old ages although the total carbonate content is large.

In order to assess whether these detrital carbonates have similar ages with different carbonate content or similar content with different ages, we also calculated the proportion of each age that is contributed by detrital carbonates $\left(=A_{\text {detr }} / A\right.$, Fig. $\left.6 \mathrm{~b}\right)$. In many cases, $A_{\text {detr }}$ increases with the proportion contributed by detrital carbonates but along different lines (the purple and blue lines in Fig. 6b). This suggests some samples are similarly pre-aged and the $A_{\text {detr }}$ increases with the proportion of their relative contributions when environmental conditions are similar. However, there are also samples that were younger when transported into the lake (the dash line and the red dot in Fig. 6b), resulting in younger $A_{\text {detr }}$ than those of similar old age contributions. For example, the red dot in in Fig. $6 \mathrm{~b}$ indicates it contains younger $A_{\mathrm{detr}}$ but contributes more than $30 \%$ of the dated age. Such features of these old ages suggest it may not be possible to assume a constant 'old-age' for the detrital carbonates. This is supported by the three surface paleolake sediment samples to the northwest of the lake (Fig. 3), whose radiocarbon ages range from $14550 \pm 50$ to $16690 \pm 60{ }^{14} \mathrm{C}$ yr BP. Although a similar pattern is not observed in Lake Bosten due to fewer extremely old ages along the sequence (Fig. 5b), it is clear in Lake Gahai detrital carbonates of different ages were mixed in the sediments that have been dated. This is also supported by the offset between the extremely old ages and the four mollusk shell ages (Fig. 5a), varying from c. 1900 to $7260{ }^{14} \mathrm{C}$ years. Therefore, it is reasonable to assess the contribution of detrital carbonates to old ages by the determining the offset between the dated ages and the $A_{2}$ line which the shell ages generally follow in Lake Gahai (Fig. 5a).

For the reversed old ages in core BST04H in Lake Bosten, we use the same method as in Lake Gahai to estimate the old ages contributed by detrital carbonates with equation (4) as samples below and above $300 \mathrm{~cm}$ of BST4H clearly suggest extremely old ages result from detrital carbonate contribution. Three younger ages could not be included in the $A_{l}$ regression line for Lake Bosten (Fig. 5b). The ages at $20.5 \mathrm{~cm}\left(2688 \pm 30{ }^{14} \mathrm{C} \mathrm{yr} \mathrm{BP}\right)$ and $550.2 \mathrm{~cm}$ 
(9755 $\pm 40{ }^{14} \mathrm{C}$ yr BP) however can still be used. As shown in the preliminary regressions for BST04H (Supplementary Fig. S3e, S3f), if these two points are included, the calculated intercept is $2625 \pm 136$ (linear) and $2617 \pm 226$ (quadratic) ${ }^{14} \mathrm{C}$ yr BP, indicating preliminary regressions are strongly influenced by these younger ages after all old ages are excluded, and the intercepts are closer to the RE of the younger ages. As both lie to the left of the regression line with similar feature in Fig.5b, we use $2600 \pm 25{ }^{14} \mathrm{C}$ yr BP as the RE for these two depths assuming they contain a similar RE. Whether such an assumption is correct can be verified after the chronology is established. For the remaining one younger age at $122.3 \mathrm{~cm}$ (3840 \pm $30{ }^{14} \mathrm{C} \mathrm{yr} \mathrm{BP}$ ) it is difficult to assess the RE as there are no suitable analogues, although we know the RE in this sample is between $2600{ }^{14} \mathrm{C}$ yr BP and $3464{ }^{14} \mathrm{C}$ years (Fig. 5b). Therefore, we have chosen to discard the younger age at $122.3 \mathrm{~cm}$ in establishing our new chronology.

Fig. 6

\subsection{Establishment of a chronology}

After assessing the different REs for radiocarbon ages by determining $A_{1}$ and $A_{2}$ for the GHB core and the old carbon ages contributed by detrital carbonates $\left(A_{\text {detr }}\right)$ for both cores, the RE-corrected ${ }^{14} \mathrm{C}$ ages ('conventional' ages in Table 2) can be obtained through:

$A^{\prime}=\left\{\begin{array}{l}A-c_{1} \\ A-c_{2} \\ A-\left(c_{2}+A_{\operatorname{det} r}\right)\end{array}\right.$

where $A^{\prime}$ is RE-corrected ${ }^{14} \mathrm{C}$ ages, $A$ is the ${ }^{14} \mathrm{C}$ ages before $\mathrm{RE}$ corrections, equations (5) and (6) are used for ages along $A_{1}$ and $A_{2}$ lines in GHB core, equation (5) is used for BST04H core, and (7) is used for the reversed older ages in both lakes. The corrected ${ }^{14} \mathrm{C}$ ages and their respective REs (or $\mathrm{RE}+A_{\text {detr }}$, Table 2) were then calibrated using the R-based Bayesian software package, Bacon (Christen and Pérez, 2010; Blaauw and Christen, 2011). In the GHB 
core, the top age was set to $-55 \pm 5$ as the core was taken in 2008 and the topmost sample covers sediments from 2006 to 2008. The calculation section ('thick' in Bacon) was set to 20 $\mathrm{cm}$ and 70 sections were used for age modeling along the $1400 \mathrm{~cm}$ core. In BST04H core, the top age was also set to $-55 \pm 5$ (as the core was taken in 2004) and the 'thick' was set to $15 \mathrm{~cm}$ (41 sections were used), and the resulting Bayesian age-depth models are shown in Fig. 7. The bottom age of the GHB core from Lake Gahai is calculated as $11420 \mathrm{Cal}$ aBP (Table 1), while the age at the depth of $600 \mathrm{~cm}$ of BST04H core is $9622 \mathrm{Cal}$ a BP, and therefore both cores span the Holocene.

Fig. 7

\subsection{Validation of the chronology}

Age models established using radiocarbon dating of bulk organic matter or carbonate can be verified in a number of ways, e.g. by counting annual laminations if preserved in lake the sediments (Liu et al., 2014) or by dating TPR samples at the same or similar depths of the inorganic samples (Zhou et al., 2015). For the most recent sediments, ${ }^{210} \mathrm{~Pb}$ ages can also be compared with the radiocarbon age model to provide verification. In Lake Gahai, the chronology of the top $24 \mathrm{~cm}$ is constrained using ${ }^{210} \mathrm{~Pb}$ ages from a nearby short core, with a terrestrial plant remain (TPR) dated at the depth of $55.05 \mathrm{~cm}$. In Lake Bosten, the ${ }^{210} \mathrm{~Pb}$ ages for the top $20 \mathrm{~cm}$ and three TPR ages from the lower parts of the core have been previously published (Chen et al., 2006; Huang et al., 2009), and they can therefore be used for a direct comparison (see Fig. 8). In Lake Gahai (Fig. 8a, b), the ${ }^{210} \mathrm{~Pb}$ was dated to $24 \mathrm{~cm}$ (CRS model, Supplementary Fig. S1, Table S1), yielding an age of $56.3 \mathrm{Cal}$ a BP, which compares well to $59.5 \mathrm{Cal}$ a BP at $24 \mathrm{~cm}$ based on our inorganic carbon age model. The TPR-based age at 55.05 $\mathrm{cm}$ is $192 \pm 25 \mathrm{Cal}$ a BP, while the inorganic carbon age dated at $57.38 \mathrm{~cm}$ is $205 \pm 40 \mathrm{Cal}$ a BP. Based on our Bayesian age model the dates at 55.05 and $57.38 \mathrm{~cm}$ are 206.7 and 217.9 Cal a BP respectively, and are therefore within dating error (Fig. 8b).

In Lake Bosten (Fig. 8c and d), the ${ }^{210} \mathrm{~Pb}$ profile for the top $20 \mathrm{~cm}$ of the parallel core of 
BST04H shows that the ${ }^{210} \mathrm{~Pb}$ age at $19.5 \mathrm{~cm}$ is $83 \mathrm{Cal}$ a $\mathrm{BP}$ (Chen et al., 2006, Supplementary S1). The radiocarbon-based age model gives an age of $90.7 \mathrm{Cal}$ a BP at 19.5 $\mathrm{cm}$, suggesting the RE of $2600 \pm 25{ }^{14} \mathrm{C}$ BP applied to $20.5 \mathrm{~cm}$ is appropriate (Fig. 8d). The age model below $300 \mathrm{~cm}$ follows the three TPR ages (Huang et al., 2009; Fig. 8c); two of the inorganic carbon ages $(502 \mathrm{~cm}$ and $396 \mathrm{~cm}$ ) are very similar to the TPR ages, and the remaining one $(335 \mathrm{~cm})$ is younger than the TPR age. The cause for this is unknown, but either the inorganic carbon age is underestimated or the TPR age is older than the real age due to a longer terrestrial residence time before being transported to the lake (Oswald et al., 2005; Zhang et al., 2006; Colman et al., 2009). However, the overall distribution of our inorganic carbon age model overlaps with the ${ }^{210} \mathrm{~Pb}$ ages at the surface and spans two of the three TPR ages below $300 \mathrm{~cm}$ (Fig. 8c and d). Previous research in Lake Bosten has suggested lake sediments above the sand layer $(550 \mathrm{~cm}$ in BST04H and ca. $900 \mathrm{~cm}$ in XBWu46) post-dates 8100 Cal a BP (Chen et al., 2006; Mischke et al., 2006; Wünemman et al., 2006; Huang et al., 2009). We have applied the same RE value as that at $20.5 \mathrm{~cm}\left(2600 \pm 25{ }^{14} \mathrm{C} \mathrm{BP}\right)$ to the age at $550.2 \mathrm{~cm}$, which gives an age estimate of $8074 \mathrm{Cal}$ a BP (Table 1), suggesting an RE value of $2600 \pm 25{ }^{14} \mathrm{C} \mathrm{BP}$ can be applied to these two younger ages also.

\section{Fig. 8}

Compared to previous cores taken from Lake Gahai and Lake Bosten, our chronologies provide a much tighter age control for both lakes. For example, two long cores drilled on the northern shore of Lake Gahai, DG02 (35 m long) and DG03 (37 m), were estimated to contain Holocene sediments (Chen et al., 2007; Cao et al., 2009; Pan and Chen, 2010; He et al., 2014), however a reliable chronology could not be established. Dating for DG03 was undertaken on plant remains and mollusk shells (Fig. 9), but the ages of plant remains are apparently not in stratigraphic order. The top TPRs ages are older, suggesting some plant remains were pre-aged before being transported into the lake. For such long cores, relatively few dating points and reversed ages make it difficult to establish a reliable chronology. In practice, only three ages including one shell age, were used to estimate the age of DG03 and the core was 
estimated to have sediments from $11 \mathrm{Cal}$ ka BP above 31m (Zhang et al., 2009). Our 14 $\mathrm{m}$-long GHB core at the water depth of $11.4 \mathrm{~m}$ in the northern part of the lake was dated to 11.4 Cal ka BP, corresponding to the sediments above $31 \mathrm{~m}$ of DG03. Lithology and dating comparison confirms our chronology is therefore reasonable (Fig. 9). For BST04H in Lake Bosten, Fig. 8c shows the improvement of the age control on this core, especially for the upper $3 \mathrm{~m}, 10$ dating points were added and provide a much better age control compared to the poor chronology without TPR ages for the upper $3 \mathrm{~m}$ when published (Huang et al., 2009).

\section{Fig. 9}

The above comparison only demonstrates parts of the inorganic carbon chronology of both cores are robust. In order to further test our chronology, we need to compare proxy records of past climate from our two lake sites with an absolutely dated record for the Holocene period that shares a common forcing, such as a regional speleothem $\delta^{18} \mathrm{O}$ record and the $\delta^{18} \mathrm{O}$ of lake carbonate. We analyzed the $\delta^{18} \mathrm{O}$ composition of carbonate $\left(\delta^{18} \mathrm{O}_{\text {carb }}\right)$ in both cores and compared them to the $\delta^{18} \mathrm{O}$ record from Kesang Cave in the Tianshan Mountains in Xinjiang, China (Cheng et al., 2012). In Lake Gahai, as the ${ }^{14} \mathrm{C}$ ages of carbonates confirm frequent detrital carbonates input in the sediments (Fig. 5a), the $\delta^{18} \mathrm{O}_{\text {carb }}$ is biased due to detrital components, especially in the lower part of the core. Therefore we choose to use the $\delta^{18} \mathrm{O}$ of ostracod shells $\left(\delta^{18} \mathrm{O}_{\mathrm{ostr}}\right)$ of Limnocythere inopinata preserved in GHB. The $\delta^{18} \mathrm{O}_{\mathrm{ostr}}$ was corrected by subtracting $0.8 \%$ according to the vital effect of this species $(=0.8 \%$, von Grafenstein et al., 1999). For Lake Bosten, as the carbonate content is quite high (>30\%, suitable for $\delta^{18} \mathrm{O}$ measurements, Leng and Marshall, 2004) and the radiocarbon ages suggest detrital carbonate contamination is minor, we use the $\delta^{18} \mathrm{O}_{\text {carb }}$ values directly. Due to different sample resolution and $\delta^{18} \mathrm{O}$ values at each site we detrended all the isotope records and filtered the data using a low-pass filter (based on Mann, 2004) to create a 200-year resolution record in order to provide an isotopic comparison at the same resolution (Fig. 10).

Fig. 10 
Comparison of the 200 -yr resolution lake $\delta^{18} \mathrm{O}$ records shows a remarkable similarity to the $\delta^{18} \mathrm{O}$ of Kesang Cave during the Holocene (Fig. 10). Prior to $8 \mathrm{Cal}$ ka BP the GHB $\delta^{18} \mathrm{O}_{\text {ostr }}$ record follows a similar trend to that observed in Kesang Cave from more positive to more negative isotope values. Despite the BST04H $\delta^{18} \mathrm{O}_{\text {carb }}$ record being shorter than $\mathrm{GHB}$ and Kesang Cave, its general decreasing isotope trend maps onto the other two isotope records (Fig. 10). After $8 \mathrm{Cal} \mathrm{ka} \mathrm{BP}$, all three sites show similar variability in $\delta^{18} \mathrm{O}$; showing an increasing trend from 8 to $5.5 \mathrm{Cal} \mathrm{ka} \mathrm{BP}$ before decreasing between 5.5 and $3 \mathrm{Cal} \mathrm{ka} \mathrm{BP}$, followed by an increase in $\delta^{18} \mathrm{O}$ values from 3 to $1 \mathrm{Cal} \mathrm{ka} \mathrm{BP}$, with similar $\delta^{18} \mathrm{O}$ variability over the last thousand years (Fig. 10). As the $\delta^{18} \mathrm{O}_{\text {ostr }}$ record from GHB is more variable during the mid-Holocene, the shift toward more negative values around $6 \mathrm{Cal}$ ka BP appears to occur earlier than in BST04H and Kesang Cave (at c. $5.5 \mathrm{Cal}$ ka BP). This may be a result of the individual nature of the chronologies. The chronological control for this period is only anchored using two dated points at $8.45 \mathrm{~m}\left(4658 \pm 40{ }^{14} \mathrm{C} \mathrm{yr} \mathrm{BP}\right)$ and $9.0 \mathrm{~m}\left(5758 \pm 50{ }^{14} \mathrm{C} \mathrm{yr}\right.$ BP) in GHB (Table 1) using the same RE $\left(5128{ }^{14} \mathrm{C}\right.$ yrs, Fig. 5a). Calibrated ages in the $2 \sigma$ range at $8.45 \mathrm{~m}$ are $5390 \pm 82(96.5 \%)$ and $5562 \pm 10$ (3.5\%) Cal ka BP (Fig. 9). However, Fig. 7a suggests the calibrated age at $9.0 \mathrm{~m}$ (6654 $\pm 114 \mathrm{Cal} \mathrm{ka}$ BP, 100\%) seems older compared to the lower and upper points. Therefore, the RE could have potentially been underestimated using our modelling approach for this section of the GHB core at $9.0 \mathrm{~m}$ (Fig. 9), resulting in the older modeled ages around 5.5 Cal ka BP.

If we assume the age control is correct, then the second possibility is that sedimentary rate changed in the core, which could not be captured in the age model using Bacon as the dating points are not dense enough. An earlier response of $\delta^{18} \mathrm{O}_{\text {ostr }}$ in Lake Gahai to regional environmental changes is also possible - if both the age control is correct and sedimentary process did not change - as Lake Gahai lies more than a thousand kilometers to the south of Lake Bosten and Kesang Cave (Fig. 1a). Considering the compatibility of the $\delta^{18} \mathrm{O}$ records from all three sites during other periods in Holocene, we would attribute this earlier shift at 6 Cal ka BP in GHB to the underestimation of RE at $9.0 \mathrm{~m}$ of the core. In spite of this minor 
dissimilarity, the overall compatibility of the $\delta^{18} \mathrm{O}$ records from GHB and BST04H with that of the Kesang Cave still provides a robust test of our chronologies for both cores during the Holocene. The comparison of the $\delta^{18} \mathrm{O}$ records from our lakes and Keshang Cave helps to validate our proposed chronological corrections, and also provides an excellent opportunity to compare $\delta^{18} \mathrm{O}_{\text {carb }}$ records in arid NW China.

\section{Discussion}

\subsection{Source of old carbon in the carbonate samples for ${ }^{14} \mathrm{C}$ dating}

\subsubsection{Authigenic part determined by lake water DIC}

For authigenic carbonates precipitated in the lake water column and shells living in lake water using the DIC pool, their RE is reflected by the age of the lake water DIC (Geyh et al., 1998, 1999; Zigah et al., 2011; Philippsen and Heinemeier, 2013). For lakes fed by river runoff, generally two types of old carbon sources contribute to the age of DIC in lake water:

1) The geogenic old carbon: Weathering and dissolution of parent material will add old DIC to the lake water (Fontes et al., 1996, Ascough et al., 2010; Hou et al., 2012). Carbonate dissolution of bedrock or top soil within the catchment will produce old DIC to the runoff entering the lake. In many circumstances, although the catchment contains no carbonate bedrocks, secondary calcites can also form during the decomposition of silicate minerals such as plagioclases (Arslan et al., 2006). Weathering and dissolution of such secondary old carbonates can also contribute old DIC to the lake. Re-dissolution of previously precipitated carbonates in the lake sediments can also happen (Geyh et al., 1999) and add old DIC to the lake water directly.

2) The biogenic old carbon: The decomposition of peat and organic-rich top soil emits $\mathrm{CO}_{2}$ that contains old carbon (Abbott and Stafford, 1996; Billett et al., 2007). The $\mathrm{CO}_{2}$ dissolves in the ambient water forming old DIC before entering the lake. Within the lake, this process also happens if the sediments are organic-rich and the dissolved oxygen in the bottom water is sufficient. 
For lakes fed by melt water and groundwater, old DIC in the lake water is also quite common as melt water from glaciers contains 'dead' or old carbon that has previously been trapped in the ice (Hendy and Hall, 2006) and groundwater often contains very old DIC of either geogenic or biogenic origin (Geyh et al 1998, 1999; Ascough et al., 2010, 2011).

When the source of old DIC is fixed, the age of lake water DIC depends on the exchange rate of $\mathrm{CO}_{2}$ between lake water and the atmosphere. If the DIC of the lake water does not equilibrate with the atmospheric $\mathrm{CO}_{2}$ (Fontes et al., 1996), an older (than modern carbon) age will be measured. There are several controlling factors that drive the equilibration, such as the stratification of the lake water (water depth), the wind regime that is responsible for the mixing of the lake water, and the duration of ice cover in cold regions.

In the process of assessing the RE of lake water DIC for authigenic carbonates in Lake Gahai, we can exclude old DIC of biogenic origin, as both the vegetation cover in the catchments and productivity in the lakes are low, resulting in insufficient organic matter for ${ }^{14} \mathrm{C}$ dating. In addition, the high $\mathrm{pH}$ value of the lake (8.28) is favorable for carbonate precipitation, suggesting re-dissolution processes are likely to be insignificant. The lake is shallow and unstratified; strong winds occur during winter and spring. Lake Gahai is not completely covered by ice during the winter due to its high salinity, and modern water DIC data from the Lake Gahai catchment (Fig. 3) suggests the Bayin River contains old DIC. This is most likely from carbonate dissolution within top soil or from secondary carbonates formed during the decomposition of silicate minerals such as plagioclases (Arslan et al., 2006), although the catchment contains no carbonate bedrocks. However, the DIC ages decrease rapidly to Lake Hurleg (open) and Lake Toson (closed, Fig. 3), indicating that flowing water is rapidly exchanging $\mathrm{CO}_{2}$ with the atmosphere, leading to near equilibration (Doran et al., 1999). In addition, within Lake Gahai, apart from the groundwater in the northwest corner, which gives a very old DIC age $\left(5620 \pm 30{ }^{14} \mathrm{C}\right.$ yr BP $)$, other samples in the east and south of the lake yield young DIC ages. This suggests the major source of old DIC is the groundwater from the 
northwest corner of the catchment (sampled well water appears stagnant but contains very old DIC), as the spring water on the east shore gives very young DIC ages (100 600 ${ }^{14} \mathrm{C}$ yr BP). It also implies the lake water mixes well and the ${ }^{14} \mathrm{C}$-depleted DIC is rapidly diluted and equilibrates with atmospheric $\mathrm{CO}_{2}$ although it is still $240{ }^{14} \mathrm{C}$ yr BP in the south of the lake. The results of modern water DIC ages suggest that the RE of inorganic carbon precipitated in the lake water column is site-specific, depends on the distance to the source of old DIC input by groundwater, the further away, the smaller the RE is expected. The GHB core taken from the northern part of the lake is close to this old DIC source. Therefore, the RE in the carbonates in the core sediment will be larger than for other sites in the lake, and $<5620{ }^{14} \mathrm{C}$ years, which is the age of groundwater in this part of the basin. Our assessment of the average RE based on preliminary regression suggests it was $4764 \pm 243{ }^{14} \mathrm{C}$ yr BP, and the refined two REs of $4522 \pm 64$ and $5128 \pm 154{ }^{14} \mathrm{C} \mathrm{BP}$, all $<5620{ }^{14} \mathrm{C} \mathrm{yr} \mathrm{BP}$ of the old DIC source water, suggesting that our RE assessment for the core sediments is reasonable.

In Lake Bosten, although we don't have a detailed study of water DIC, the age-depth distribution (Fig. 4b) suggests that the water DIC at the core site in the eastern part of the lake is quite old. The Kaidu River flows from the Tianshan Mountains (the source water is distant from the lake) and the river water DIC should be nearly in equilibrium with the atmosphere (Doran et al., 1999). However, the wetland around the river mouth to the west of Lake Bosten (Fig. 1c) has had a peat deposit since the last deglaciation (Zhong and Xiong, 1998) and the decomposition of old organic matter may have contributed old DIC to the water in the river mouth flowing into the lake. In addition, the longer period of ice-cover (from November to April) may have led to insufficient lake-atmosphere exchange of $\mathrm{CO}_{2}$, resulting in the aging of DIC in the lake. Finally, the fact that the outlet of the lake water is close to the river mouth may have slowed the dilution in the eastern part of the lake by freshwater (Mischke and Wünnemann, 2006, Fig. 1c).)

\subsubsection{Detrital part from the catchment}

Results from Lake Gahai (Fig. 6) suggest the detrital carbonates could be delivered to lake 
sediments either by water or by wind in arid regions, and their ages could be similar or different before entering the lake. In Lake Bosten, although the core is from the eastern part of the lake, some distance from the river mouth, there is still the possibility for fine grained carbonates that have been eroded from soil or old lacustrine sediments along the Kaidu River to be transported to the core site. This increases the difficulty in dating carbonate samples for chronological purposes, particularly if there are no shells for comparison, and it is hard to make use of the extremely old ages. In practice, we compared ages of carbonate samples and mollusk shells at the same depths in GHB core to assess the contribution of old ages in the detrital carbonates (Section 5.3. and Fig. 5a). Shells gave ages in good stratigraphic order and apparently younger than the carbonate ages suggested they were preserved in-situ and may be more reliable than bulk carbonates for dating purposes. Therefore, our results suggest if carbonate samples have to be used for establishing a chronology, a few shell ages (like in Lake Gahai) or TPR ages (like in Lake Bosten) are still necessary for RE and detrital old carbon assessment so that the authigenic carbonates and the detrital components can be identified by ages of shells (as in GHB) or TPR at the same depths (as in BST04H, Fig. 4-5).

Even though the REs for Lake Gahai and Lake Bosten have been assessed in a similar way, the sources of old carbon in the water DIC are different. For example, the groundwater with old DIC is the major source for Lake Gahai (Fig.3) and the peat land near the river mouth is the major old carbon source for Lake Bosten. When the source of old DIC is identified, the REs at the coring sites depend on the dilution rate of the lake water, which is determined by the mixing rate of the water and water-atmosphere exchange of $\mathrm{CO}_{2}$. In this process, the duration of ice cover and wind regime are important factors. On the other hand, the age of the old DIC may also have been changing due to catchment hydrology or temperature changes, which lead to carbonates of different ages being dissolved in the groundwater DIC or organic matter at different depths of the peat decomposed and contributed DIC of different ages to the river water before entering the lake. All above factors are responsible for the younger and older REs in both lakes, although this has not been investigated in detail. 


\subsection{Possibility of applying more than one RE for inorganic carbon ages to a sedimentary sequence}

The 'intercept-method' for RE assessment for a sedimentary sequence requires a precise regression equation describing the age-depth pairs. If a linear regression describes the age-depth relations well, it means both the RE and the sedimentation rate are relatively stable, e,g. Fontes et al. (1996). If a quadratic or even more complex polynomial regression is reached with higher confidence for the age-depth pair, it means the RE is around a certain value but the sedimentation rate changes. In such cases, the intercept of the polynomial equation represents the average $\mathrm{RE}$ of the dated ages and the curvature of the regression curve reflects the variations of sedimentary rates. In Lake Gahai and Bosten, we found quadratic regressions performed better than linear ones, therefore the variation of sedimentary rate change were reflected in the curvature of the regression lines (Fig. 5). For example, the curvature of the regression lines in both cores suggests a higher sedimentary rate for the upper parts of both cores (late Holocene). In Lake Gahai, the refined $\mathrm{A}_{2}$ line nearly parallels the $\mathrm{A}_{1}$ line (Fig. 5a) and confirms that the sedimentary rate determined by the two regressions are similar, but only the RE changed. Such a method is applicable for continuous sedimentary sequences without hiatuses or complicated sedimentary rate changes as in Lake Gahai and Bosten. If there are hiatuses or frequent sedimentary rate variations, this method may not be applicable. For a continuous sedimentary sequence, if it is densely dated on the same material (similar carbon source), it is possible to find more than 2 similar equations with different intercepts for RE assessment as shown Fig. 5a for GHB core. The important principle here is the refined regression equations should be as similar as possible to the preliminarily observed regression equation (from Fig. 4a to Fig. 5a) so that the overall age-depth relationship is not significantly changed (as the sedimentary rate of a sequence is fixed).

The assumption of a constant RE, which is assessed by extrapolation, on the basis of the radiocarbon age of modern sediment or modern DIC ages with radiocarbon dates is often unjustified as our cases in both GHB and BST04H demonstrate. The modern DIC ages within a lake are site-specific (Fig. 3) and the age of top sediments under-estimates the RE of many 
dated ${ }^{14} \mathrm{C}$ ages down core (Fig. 5). In addition, the work of Liu et al. (2014) from Kusai Lake has shown the RE is not constant. Although the varve counting indicates a stable

sedimentation rate, the ${ }^{14} \mathrm{C}$ ages became older than the varve ages in the lower parts of the core, suggesting one RE is not enough to make use of the radiocarbon ages. Recently more than one RE has been applied to one sedimentary sequence, for example in Lake Qinghai (An et al., 2012; Zhou et al., 2014) although based on different calculations, suggesting the necessity of finding more practical ways to assess more than one constant RE for samples containing old carbon, especially when both the RE and sedimentary rate changed due to hydrological condition shifts resulting from regional climate changes in the past.

\section{Conclusion}

Inorganic carbon dating from a small-enclosed saline lake and large freshwater lake in NW China was systematically studied for the possibility of establishing an inorganic carbon chronology. Results suggest the traditional assumption of one constant RE may not be realistic for inorganic carbon dating in lake sediments in arid regions. Our method of applying refined regressions suggest authigenic carbonates precipitated from the water column using DIC generally have an average RE of $c .4760{ }^{14} \mathrm{C}$ years in Lake Gahai and $3400{ }^{14} \mathrm{C}$ years in Lake Bosten, but could be smaller $\left(4522{ }^{14} \mathrm{C}\right.$ years in Gahai; ca. $2600{ }^{14} \mathrm{C}$ years in Bosten) and larger $\left(5128{ }^{14} \mathrm{C}\right.$ years in Gahai; $3464{ }^{14} \mathrm{C}$ years in Bosten). Modern water DIC ages in the drainage basin suggest it is site-specific either within the catchment or within the lake. They are useful in providing information on identifying the source water with old DIC, but cannot be used as the reservoir age for calibrating the authigenic carbonates ages in the core sediments. Calcium carbonate shells or even a few TPR samples should be dated if possible to provide additional assessment of the reservoir age of the water DIC and the extremely old ages contributed by the detrital carbonates. Detrital carbonates seem to be frequently transported into the lake either by inflowing water in wetter periods or by wind in drier periods. If the old ages contributed by both authigenic DIC part and/or the detrital component are properly assessed, our method could be used to establish a reliable chronology for both saline and freshwater lakes in arid regions where terrestrial plant remains are rare. 
Acknowledgements: This research is supported by the National Science Foundation of China (NSFC 41271220), the National Basic Research Program of China (Grant No: 2012CB956102), and the NSFC key project (41130102). Lei Song, Guangming Liu, Hui Li attended the fieldwork. We also thank Professor Bernd Wünnemann and Professor Juzhi Hou for their constructive suggestions in improving the quality of the manuscript.

\section{References}

An, Z., Colman, S.M., Zhou, W., Li, X., Brown, E.T., Jull, A.J.T., Cai, Y., Huang, Y., Lu, X., Chang, H., Sun, Y., Xu, H., Liu, W., Jin, Z., Liu, X., Cheng, P., Liu, Y., Ai, L., Li, X., Liu, X., Yan, L., Shi, Z., Wang, X., Wu, F., Qiang, X., Dong, J., Lu, F., Xu, X., 2012. Interplay between the Westerlies and Asian monsoon recorded in Lake Qinghai sediments since $32 \mathrm{ka}$. Scientific Reports 2, 619, DOI:10.1038/srep00619.

Arslan, M., Kadir, S., Abdiglu, E., Kolayli, H., 2006. Origin and formation of kaolin minerals in saprolite of Tertiary alkaline volcanic rocks, Eastern Pontides, NE Turkey. Clay Minerals 41, 597-617.

Ascough, P.L., Cook, G.T., Church, M.J., Dunbar, E., Einarsson, Á., McGovern, T,H., Dugmore, A.J., Perdikaris, S., Hastie, H., Friðricksson, A., Gestsdóttir, H., 2010. Temporal and spatial variations in freshwater ${ }^{14} \mathrm{C}$ reservoir effects: Lake Mývatn, northern Iceland. Radiocarbon 52(2-3), 1098-1112.

Ascough, P. L., Cook, G.T., Hastie, H., Dunbar, E., Church, M.J., Einarsson, Á., McGovern, T.H., Dugmore, A.J., 2011. An Icelandic freshwater radiocarbon reservoir effect: Implications for lacustrine ${ }^{14} \mathrm{C}$ chronologies. The Holocene 21(7), 1073-1080.

Abbott, M.B., Stafford Jr, T.W., 2006. Radiocarbon geochemistry of modern and ancient Arctic lake systems, Baffin Island, Canada. Quaternary Research 45, 300-311.

Bertrand, S., Araneda, A., Vargas, P., Jana, P., Fagel, N., Urrutia, R., 2012. Using the N/C ratio to correct bulk radiocarbon ages from lake sediments: Insights from Chilean Patagonia. Quaternary Geochronology 12, 23-29.

Billett, M., Garnett, M.H., Harvey, F. UK peatland streams release old carbon dioxide to the 
atmosphere and young dissolved organic carbon to rivers. Geophysical Research Letters, 34, L23401, doi:10.1029/2007GL031797.

Blaauw, M., Christen, J.A., 2011. Flexible paleoclimate age-depth models using an autoregressive gamma process. Bayesian Analysis 6(3), 457-474.

Bronk Ramsey, C., 2008. Deposition models for chronological records. Quaternary Science Reviews 27(1-2), 42-60.

Bronk Ramsey, C., Lee ,S., 2013. Recent and planned developments of the program OxCal. Radiocarbon 55(2-3), 720-730.

Bronk Ramsey, C., Schulting, R., Goriunova, O.I., Bazaliiskii, V.I., Weber, A.W., 2014. Analyzing radiocarbon reservoir offsets through stable nitrogen isotopes and Bayesian modeling: a case study using paired human and faunal remains from the cis-Baikal region, Siberia. Radiocarbon 56(2), 789-799.

Cao, G., Ma, H., Zhang, P., Chen, Z., Zhang, X., Gao, D., Han, F., 2009. Geochemical composition of sediment in Gahai Lake since $11.5 \mathrm{ka} \mathrm{BP}$ and its environmental implication. Ata Sedimentologica Sinica 27(2), 360-366 (in Chinese with English abstract).

Chen, F., Huang, X., Zhang, J., Holmes, J.A., Chen, J., 2006. Humid Little Ice Age in arid central Asia documented by Bosten Lake, Xinjiang, China. Science in China Series D: Earth Sciences 49(12): 1280-1290.

Chen, Z., Ma, H., Cao, G., Zhang, X., Zhou, D., Yao, Y., Tan, H., Gao, Z., 2007. Climate-environmental evolution in Gaihai Lake area of Qaidam Basin since late last deglacial period. Geochimica, 36(6), 633-637 (in Chinese with English abstract).

Cheng, H., Zhang, P.Z., Spötl, C., , Edwards, R.L., Cai, Y. J., Zhang, D. Z., Sang, W. C., Tan, M., An, Z. S., 2012. The climatic cyclicity in semiarid- arid central Asia over the past 500,000 years, Geophysical Research Letters 39, L01705, doi:10.1029/2011GL050202.

Christen, J.A., Pérez E., S., 2010. A new robust statistical model for radiocarbon data. Radiocarbon 51, 1047-1059.

Cook, G.T., Bonsall, C., Hedges, R.E.M., McSweeney, K., Boroneanc, V., Pettitt, P.B., 2001. A freshwater diet-derived C-14 reservoir effect at the Stone Age sites in the Iron Gates 
gorge. Radiocarbon 43(2), 453-460.

Colman, S.M., Rosenbaum, J.G., Kaufman, D.S., Dean, W.E., and McGeehin, J.P., 2009. Radiocarbon ages and age models for the past 30,000 years in Bear Lake, Utah and Idaho. In Rosenbaum, J.G., and Kaufman, D.S., eds., Paleoenvironments of Bear Lake, Utah and Idaho, and its catchment: Geological Society of America Special Paper 450, $133-144$.

Dee, M., Bronk Ramsey, C., 2014. High-precision Bayesian modeling of samples susceptible to inbuilt age. Radiocarbon 56(1), 83-94.

Doran, P.T., Berger, G.W., Lyons, W.B., Wharton Jr., R.A., Davisson, M.L., Southon, J., Dibb, J.E., 1999. Dating Quaternary lacustrine sediments in the McMurdo Dry Valleys, Antarctica. Palaeogeography, Palaeoclimatology, Palaeoecology 147, 223-239.

Fan, Q.S., Lai, Z.P., Long „H., Sun, Y.J., Liu, X.J., 2010. OSL chronology for lacustrine sediments recording high stands of Gahai Lake in Qaidam Basin, northeastern Qinghai-Tibetan Plateau. Quaternary Geochronology 5, 223-227.

Fontes, J.C., Gasse, F., Gibert, E., 1996. Holocene environmental changes in Lake Bangong basin (Western Tibet). Part 1: Chronology and stable isotopes of carbonates of a Holocene lacustrine core. Palaeogeography, Palaeoclimatology, Palaeoecology 120, $25-47$.

Gasse, F., Arnold, M., Fontes, J.C., Gibert, E., Huc, A., Li, B.Y., Li, Y.F., Liu, Q., Mélières, F., Van Campo, E., Wang, F., Zhang, Q.S., 1991. A 13,000-year climate record from western Tibet. Nature 353, 742-745.

Geyh, M.A., Schotterer, U., Grosjean, M., 1998. Temporal Changes of the ${ }^{14}$ C reservoir effect in lakes. Radiocarbon 40(2), 921-931.

Geyh, M.A., Grosjean, M., Nunez, L., Schotterer, U., 1999. Radiocarbon reservoir effect and the timing of the Late-Glacial/Early Holocene phase in the Atacama Desert (Northern Chile). Quaternary Research 52, 143-153.

Groot, M.H.M., van der Plicht, J., Hooghiemstra, H., Lourens, L.J., Rowe, H.D., 2014. Age modelling for Pleistocene lake sediments: A comparison of methods from the Andean Fúquene Basin (Colombia) case study. Quaternary Geochronology 22, 144-154. 
Hart, J.P., 2014. A model for calculating freshwater reservoir offsets on AMS-dated charred, encrusted cooking residues formed from varying resources. Radiocarbon 56(3), 981-989.

He, Y., Zheng, Y., Pan, A., Zhao, C., Sun, Y., Song, M., Zheng, Z., Liu Z., 2014. Biomarker-based reconstructions of Holocene lake-level changes at Lake Gahai on the northeastern Tibetan Plateau. The Holocene 24(4), 405-412.

Henderson, A.C.G., Holmes, J.A., 2009. Palaeolimnological evidence for environmental change over the past millennium from Lake Qinghai sediments: a review and future research prospective. Quaternary International 194, 134-147.

Henderson, A.C.G., Holmes, J.A., Leng, M.J., 2010. Late Holocene isotope hydrology of Lake Qinghai, NE Tibetan Plateau: effective moisture variability and atmospheric circulation changes. Quaternary Science Reviews 29, 2215-2223.

Hendy, C.H., Hall, B.L., 2006. The radiocarbon reservoir effect in proglacial lakes: Examples from Antarctica. Earth and Planetary Science Letters 241, 413- 421.

Hou, J., D'Andrea, W.J., Liu Z., 2012. The influence of ${ }^{14} \mathrm{C}$ reservoir age on interpretation of paleolimnological records from the Tibetan Plateau. Quaternary Science Reviews 48, $67-79$.

Huang, X.Z., Chen, F.H., Fan, Y.X., Yang, M.L., 2009. Dry late-glacial and early Holocene climate in arid central Asia indicated by lithological and palynological evidence from Bosten Lake, China. Quaternary International 194, 19-27.

Kramer, A., Herzschuh, U., Mischke, S., Zhang, C., 2010. Late glacial vegetation and climate oscillations on the southeastern Tibetan Plateau inferred from the Lake Naleng pollen profile. Quaternary Research 73, 324-335.

Kusakabe, M., 2001. A simple method for sampling total dissolved carbonate in carbonate-rich natural waters and $\mathrm{CO}_{2}$ preparation for $\delta^{13} \mathrm{C}$ determination. Geochemical Journal 35, 459-464.

Lanting, J.N., van der Plicht, J., 1998. Reservoir effect and apparent ${ }^{14} \mathrm{C}$ ages. Journal of Irish Archaeology 9, 151-65.

Leng, M.J., Marshall, J.D., 2004. Paleoclimate interpretation of stable isotope data from lake sediment archives. Quaternary Science Reviews 23, 811-831. 
Li, X., Liu ,W., Xu, L., 2012. Stable oxygen isotope of ostracods in recent sediments of Lake Gahai in the Qaidam Basin, northwest China: The implications for paleoclimatic reconstruction. Global and Planetary Change 94-95, 13-19.

Liu, X., Yu, Z., Dong, H., Chen, H.F., 2014. A less or more dusty future in the Northern Qinghai-Tibetan Plateau? Scientific Reports 4 : 6672, DOI: 10.1038/srep06672.

Mann, M.E., 2004. On smoothing potentially non-stationary climate time series. Geophysical Research Letters 31, L07214, doi:10.1029/2004GL019569.

Millard, A.R., 2014. Conventions for reporting radiocarbon determinations. Radiocarbon $56(2), 555-559$.

Mischke, S., Wünnemann, B., 2006. The Holocene salinity history of Bosten Lake (Xinjiang, China) inferred from ostracod species assemblages and shell chemistry: Possible palaeoclimatic implications. Quaternary International 154-155, 100-112.

Mischke, S., Aichner, B., Diekmann, B., Herzschuh, U., Plessen, B., Wünnemann, B., Zhang, C. J., 2010. Ostracods and stable isotopes of a late glacial and Holocene record from the NE Tibetan Plateau. Chemical Geology 276, 95-103.

Mischke, S., Weynell, M., Zhang, C., Wiechert, U., 2013. Spatial variability of ${ }^{14} \mathrm{C}$ reservoir effects in Tibetan Plateau lakes. Quaternary International, 313-314:147-155

Olsen, J, Heinemejer, J, Lübcke, H, Lüth, F, Terberger, T. 2010. Dietary habits and freshwater reservoir effects in bones from a Neolithic NE German cemetery. Radiocarbon 52(2), $635-44$.

Oswald, W.W., Anderson, P.M., Brown ,T.A., Brubaker, L.B., Hu, F.S., Lozhkin, A.V., Tinner, W., Kaltenrieder, P., 2005. Effects of sample mass and macrofossil type on radiocarbon dating of arctic and boreal lake sediments. The Holocene 15(5), 758-767.

Pan, A., Chen, B., 2010. Late Quaternary plaeoenvironment in Lake Gahai, Qaidam Basin. China Meteorological Press (Beijing), 1-137 (in Chinese).

Philippsen, B., Heinemeier, J., 2013. Freshwater reservoir effect variability in northern Germany. Radiocarbon 55(2-3), 1085-101.

Reimer, P.J., Bard, E., Bayliss, A., Beck, J.W., Blackwell, P.G., Ramsey, C.B., Buck, C.E., Cheng, H., Edwards, R.L., Friedrich, M., Grootes, P.M., Guilderson, T.P., Haflidason, H., 
Hajdas, I., Hatté, C., Heaton, T.J., Hoffmann, D.L., Hogg, A.G., Hughen, K.A., Kaiser, K.F., Kromer, B., Manning, S.W., Niu, M., Reimer, R.W., Richards, D.A., Scott, E.M., Southon, J.R., Staff, R.A., Turney, C.S.M., van der Plicht, J., 2013. Intcal13 and Marine13 radiocarbon age calibration curves 0-50,000 years Cal BP. Radiocarbon 55(4), $1869-1887$.

Shen, J., Liu, X., Wang, S., Matsumoto, R., 2005. Palaeoclimatic changes in the Qinghai Lake area during the last 18,000 years. Quaternary International 136, 131-140.

Shishlina, N.I., van der Plicht, J., Hedges, R.E.M., Zazovskaya, E.P., Sevastyanov, V.S., Chichagova, O.A., 2007. The Catacomb cultures of the north-west Caspian steppe: ${ }^{14} \mathrm{C}$ chronology, reservoir effect, and paleodiet. Radiocarbon 49(2), 713-726.

Shishlina, N.I., Zazovskaya, E.P., van der Plicht, H, Sevastyanov, V.S., 2012. Isotopes, plants, and reservoir effects: case study from the Caspian steppe Bronze Age. Radiocarbon 54(3-4), 749-760.

Soulet, G., Ménot, G., Garreta, V., Rostek, F., Zaragosi, S., Lericolais, G., Bard, E., 2011. Black Sea "Lake" reservoir age evolution since the Last Glacial - Hydrologic and climatic implications. Earth and Planetary Science Letters 308, 245-258.

Stuiver, M., Robinson, S. W., 1974, University of Washington Geosecs North Atlantic carbon-14 results: Earth and Planetary Science Letters 23, 87-90.

Stuiver M., Polach H.A., 1977. Discussion: Reporting of ${ }^{14}$ C Data. Radiocarbon 19(3), $355-363$.

von Grafenstein, U., Erlernkeuser, H., Trimborn, P., 1999. Oxygen and carbon isotopes in modern fresh-water ostracod valves: assessing vital offsets and autecological effects of interest for palaeoclimate studies. Palaeogeography, Palaeoclimatology, Palaeoecology 148:133-152.

Watanabe, T., Matsunaka, T., Nakamura, T., Nishimura, M., Izutsu, Y., Minami, M., Nara, F. W., Kakegawa, T., Wang, J., Zhu, L., 2010. Last glacial-Holocene geochronology of sediment cores from a high-altitude Tibetan lake based on $\mathrm{AMS}{ }^{14} \mathrm{C}$ dating of plant fossils: Implications for paleoenvironmental reconstructions. Chemical Geology 277, $21-29$. 
Watanabe, T., Nakamura, T.,Matsunaka, T., Nara, F.W., Zhu, L., Wang, J., Kakegawa, T., Nishimura, M., 2013. A chronology of the PY608E-PC sediment core (Lake Pumoyum Co, southern Tibetan Plateau) based on radiocarbon dating of total organic carbon. Nuclear Instruments and Methods in Physics Research B 294, 520-523.

Wood, RE, Higham, T, Buzilhova, A, Surorov, A, Heinemeier, J, Olsen, J. 2013. Freshwater radiocarbon reservoir effects at the burial ground of Minino, northwest Russia. Radiocarbon 55(1), 163-177.

Wu, Y.., Lücke, A., Jin, Z., Wang, S., Schleser, G.H., Battarbee, R.W., Xia, W., 2006. Holocene climate development on the central Tibetan Plateau: a sedimentary record from Cuoe Lake. Palaeogeography, Palaeoclimatology, Palaeoecology 234, 328-340.

Wu, Y. H., Li, S. J., Lücke, A., Wünnemann, B., Zhu, L. P., Reimer, P., Wang, S. M., 2010. Lacustrine radiocarbon reservoir ages in Co Ngoin and Zige Tangco, central Tibetan Plateau. Quaternary International 212, 21-25.

Wünnemann, B., Chen, F., Riedel, F., Zhang, C., Mischke, S., Chen, G., Demske, D., Jin, M., 2003. Holocene lake deposits of Lake Bosten, southern Xinjiang, China. Chinese Science Bulletin 48, 1429-1432.

Wünnemann, B., Mischke, S., Chen, F., 2006. A Holocene sedimentary record from Bosten lake, China. Palaeogeography, Palaeoclimatology, Palaeoecology 234, 223-238.

Yang, X., Ma, N., Dong, J., Zhu, B., Xu, B., Ma, Z., Liu, J., 2010. Recharge to the inter-dune lakes and Holocene climatic changes in the Badain Jaran Desert, western China. Quaternary Research 73, 10-19.

Yang, X., Scuderi, L.A., Wang, X., Scuderi, L.J., Zhang, D., Li, H., Forman, S., Xu, Q., Wang, R., Huang, W., Yang, S., 2015. Groundwater sapping as the cause of irreversible desertification of Hunshandake Sandy Lands, Inner Mongolia, northern China. Proceedings of National Academy of Sciences 112(3), 702-706.

Yu, S.Y., Shen, J., Coleman, S.M., 2007. Modeling the radiocarbon reservoir effect in lacustrine systems. Radiocarbon 49(3), 1241-1254.

Yu, S.Y., Cheng, P., Hou, Z.F., 2014. A caveat on radiocarbon dating of organic-poor bulk lacustrine sediments in arid China. Radiocarbon 56(1), 127-141. 
Zhang, C., Mischke, S., 2009. A Lateglacial and Holocene lake record from the Nianbaoyeze Mountains and inferences of lake, glacier and climate evolution on the eastern Tibetan Plateau. Quaternary Science Reviews 28, 1970-1983.

Zhang, C., Feng, Z., Yang, Q., Gou, X., Sun, F., 2010. Holocene environmental variations recorded by organic-related and carbonate-related proxies of the lacustrine sediments from Bosten Lake, northwestern China. The Holocene 20, 363-373.

Zhang, H.C., Ming, Q.Z., Lei, G.L., Zhang, W.X., Fan, H.F., Chang, F.Q., Wünnemann, B., Hartmann, K., 2006. Dilemma of dating on lacustrine deposits in a hyperarid inland basin of NW China. Radiocarbon 48(2), 219-226.

Zhao, Y., Yu, Z., Chen, F., Liu, X., Ito, E., 2008. Sensitive response of desert vegetation to moisture change based on a near-annual resolution pollen record from Gahai Lake in the Qaidam Basin, northwest China. Global and Planetary Change 62, 107-114.

Zhao, C., Liu, Z., Rohling, E.J., Yu, Z., Liu, W., He, Y., Zhao, Y., Chen, F., 2013. Holocene temperature fluctuations in the northern Tibetan Plateau. Quaternary Research 80, 55-65.

Zhong, W., Xiong, H., 1998. Isotopic evidence for Holocene climatic changes in Bosten Lake, southern Xinjiang, China. Chinese Geographical Science 8(2), 176-182.

Zhou, A.F., Chen F.H., Wang Z.L., Yang, M.L., Qiang, M.R., Zhang, J. W., 2009. Temporal change of radiocarbon reservoir effect in Sugan Lake, northwest China during the Late Holocene. Radiocarbon 51(2), 529-535.

Zhou, A., He, Y., Wu, D., Zhang, X., Zhang, C., Liu, A., 2015. Changes in the radiocarbon reservoir Age in Lake Xingyun, southwestern China during the Holocene. PLoS ONE 10(3): e0121532. doi:10.1371/journal.pone.0121532.

Zhou, W., Cheng, P., Timothy Jull, A. J., Lu, X, An, Z., Wang, H., Zhu, Y., Wu, Z., 2014. ${ }^{14}$ C Chronostratigraphy for Qinghai Lake in China. Radiocarbon 56(1), 143-155.

Zigah, P.K., Minor, E.C., Werne, J.P., McCallister, S.L., 2011. Radiocarbon and stable carbon isotopic insights into provenance and cycling of carbon in Lake Superior. Limnology and Oceanography 56(3), 867-886. 
Figures
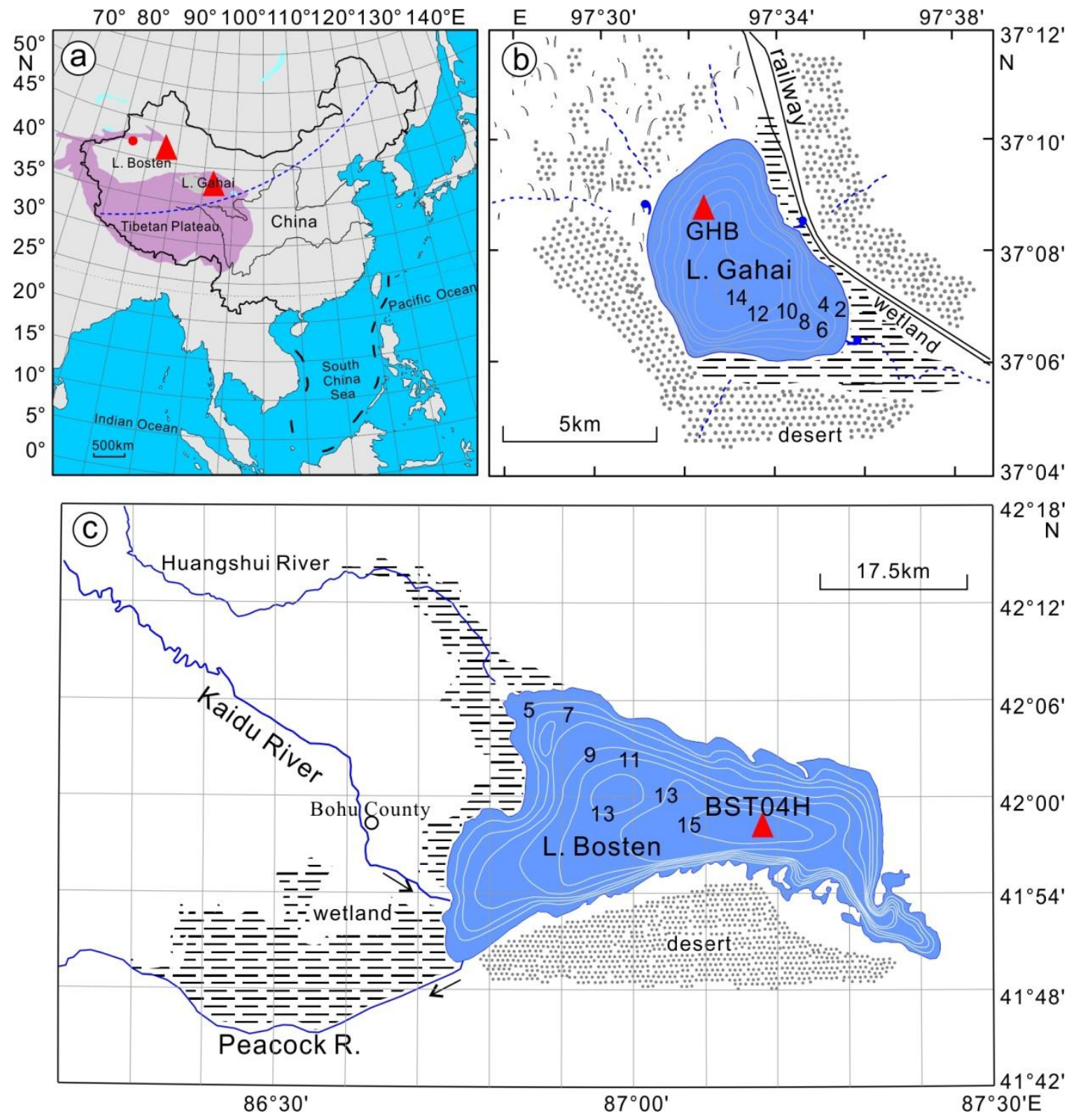

Fig. 1 
(a)

GHB from Lake Gahai

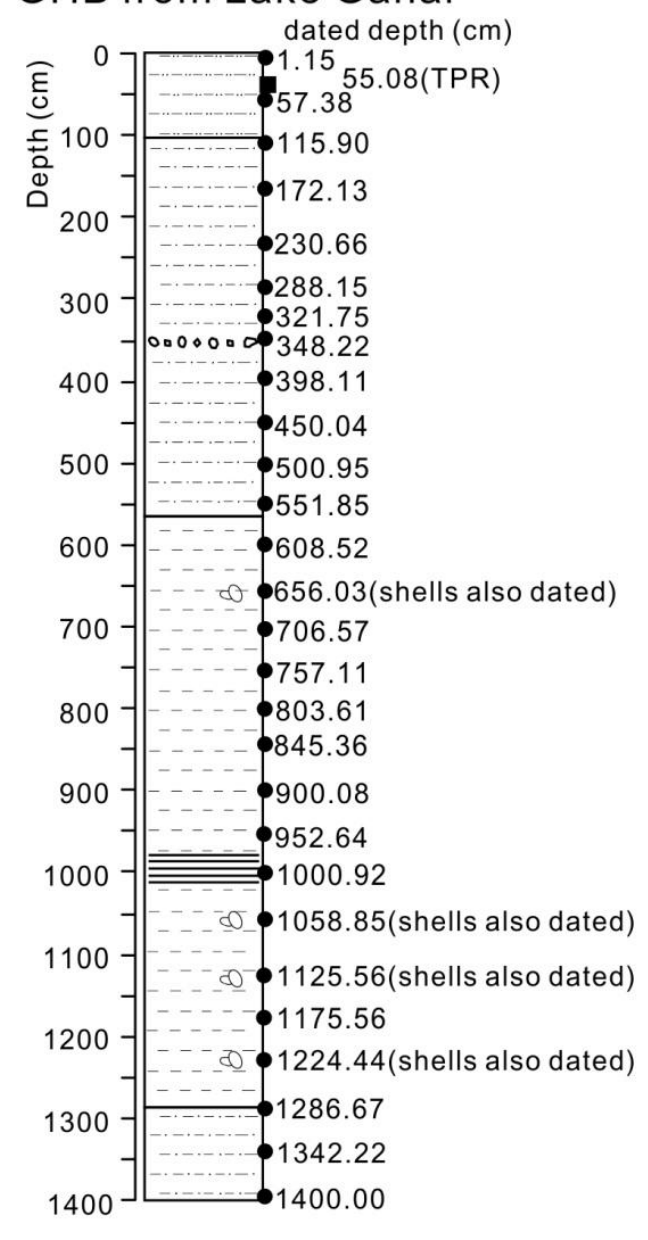

(b)

BST04H from Lake Bosten

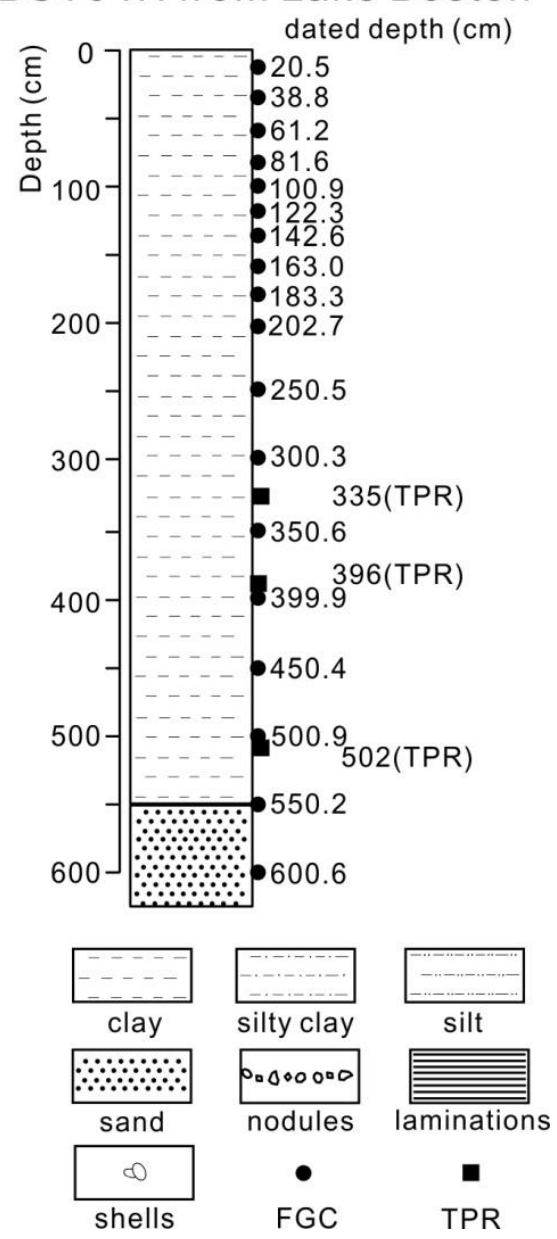

Fig. 2 


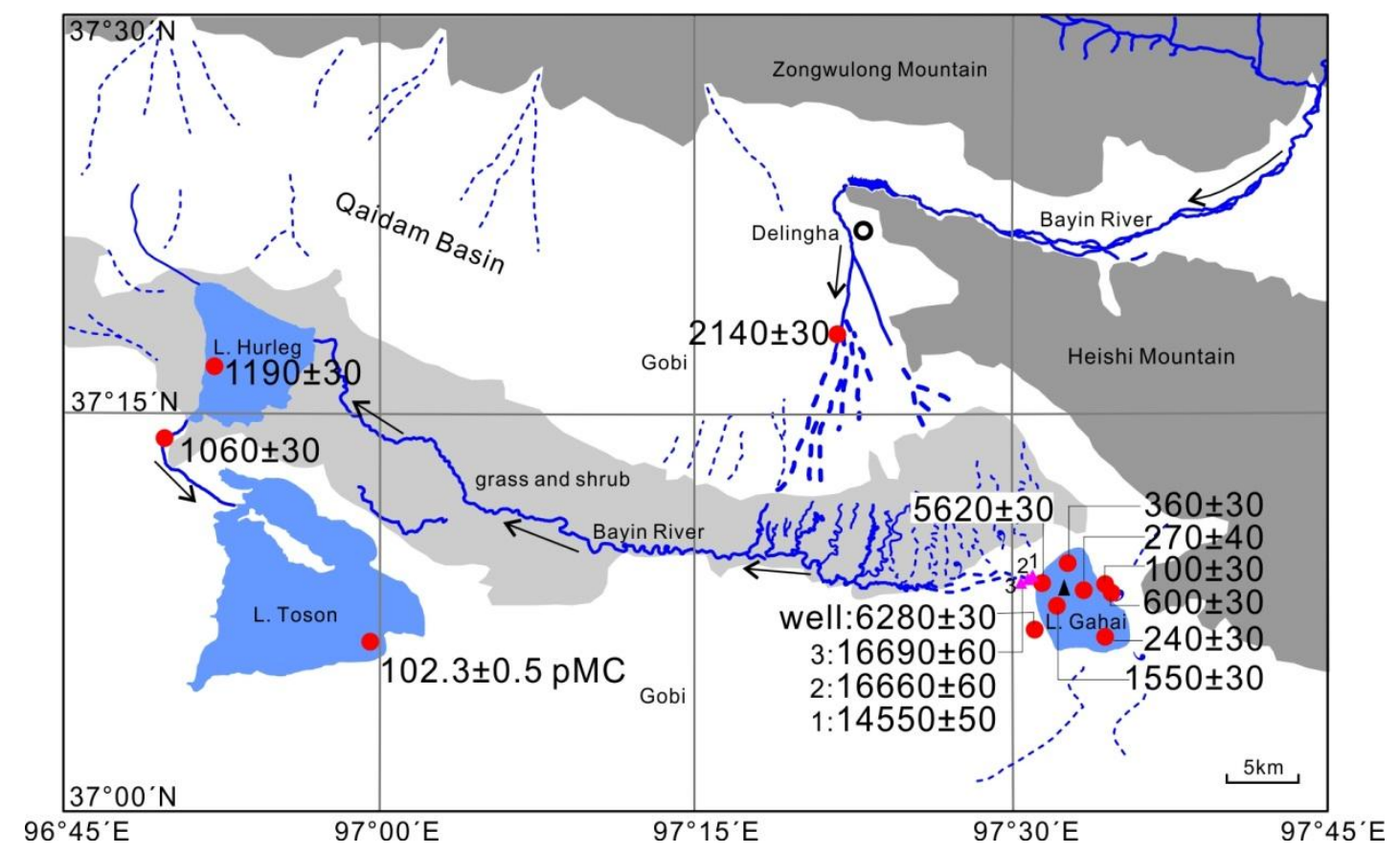

Fig. 3 


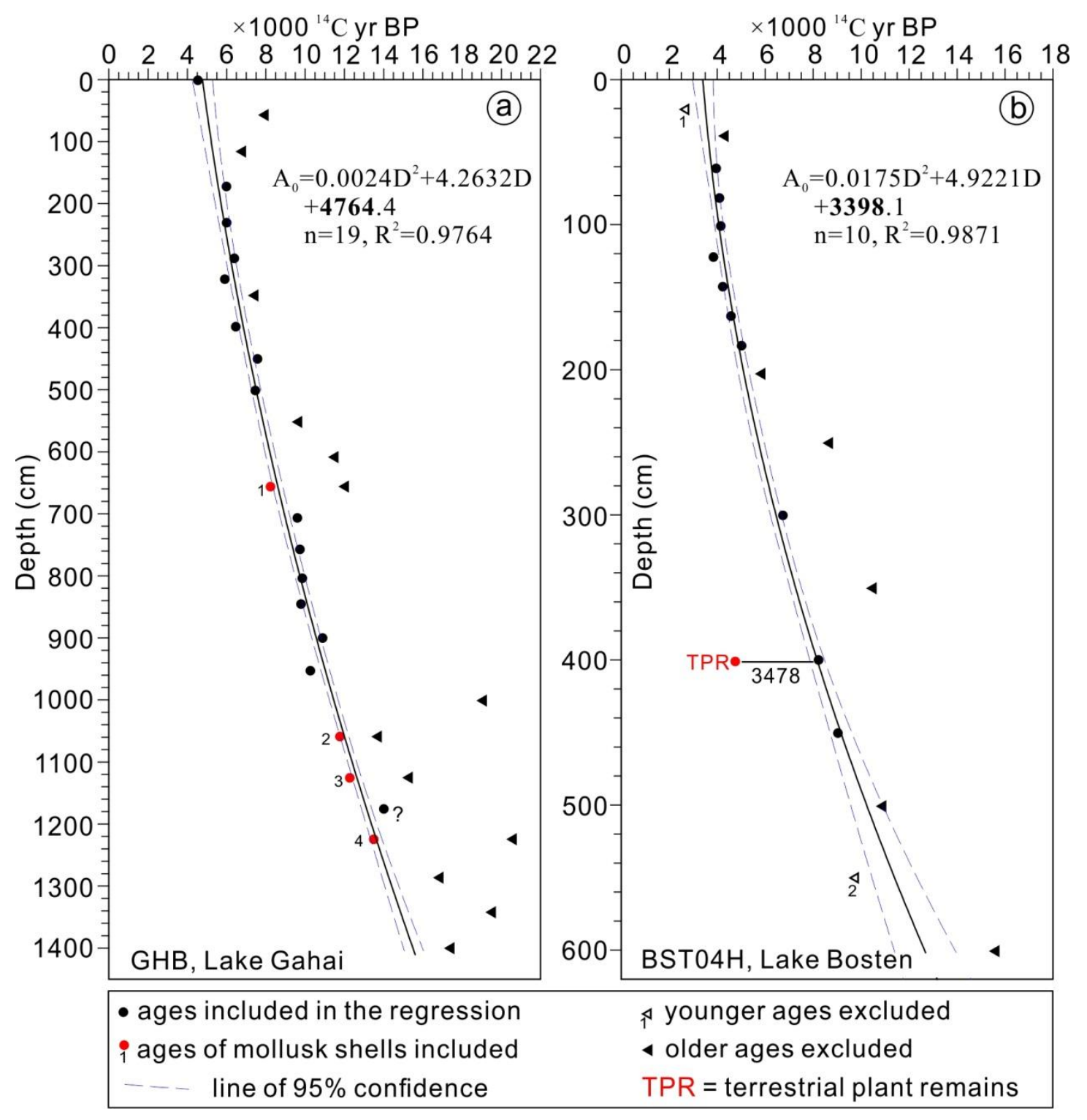

Fig. 4 


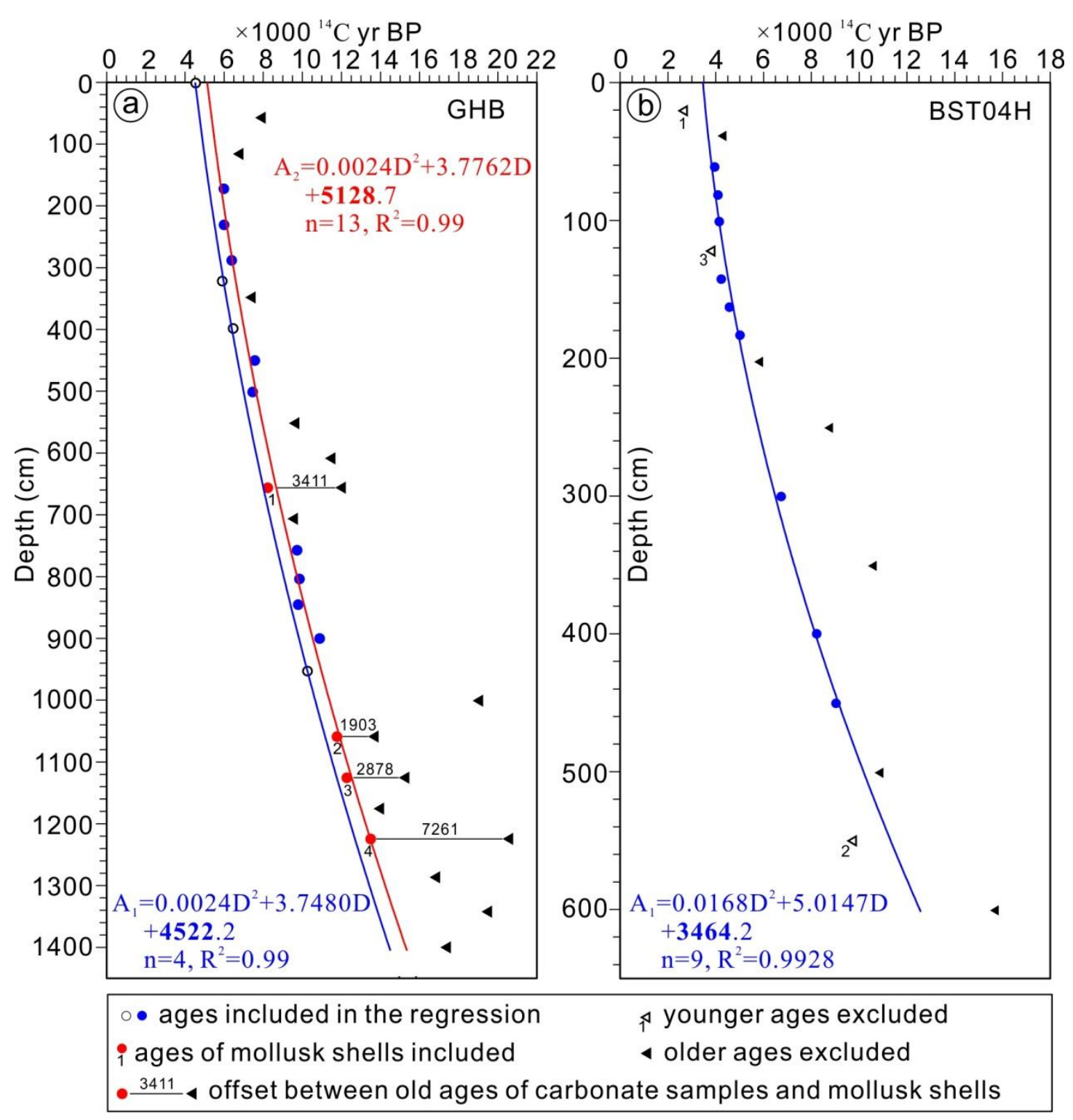

Fig. 5
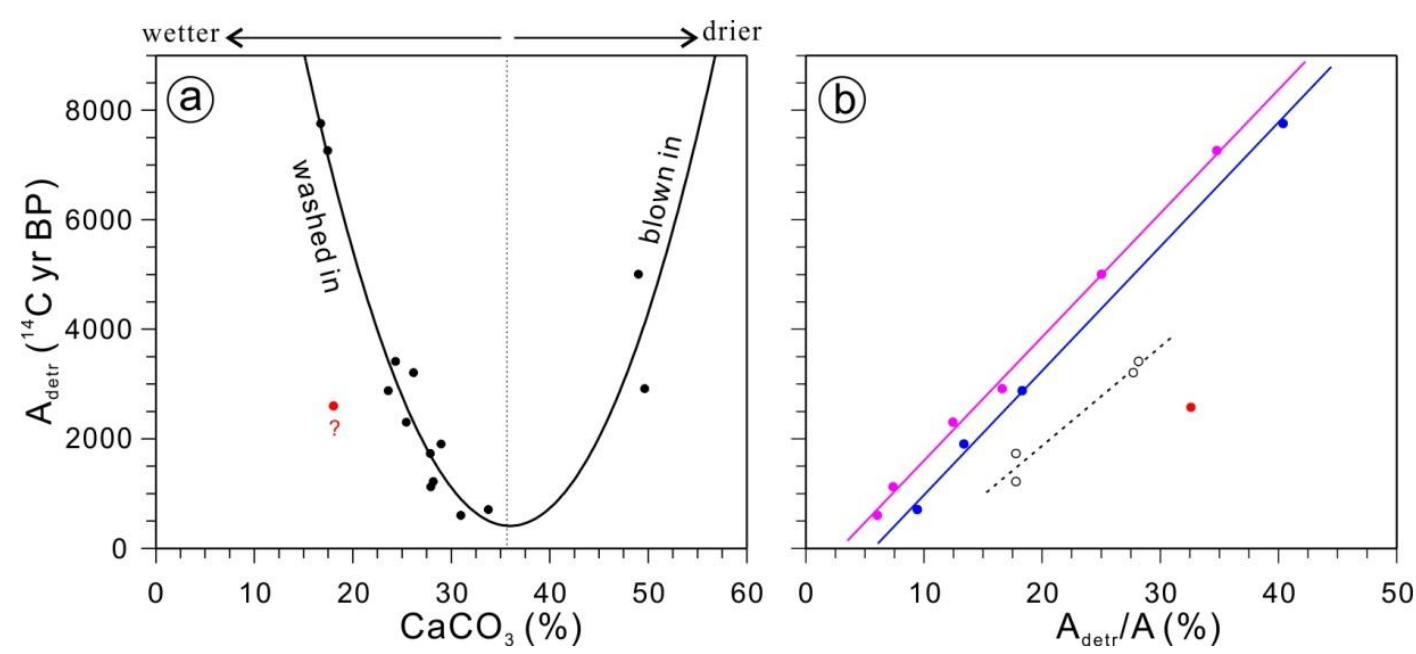

Fig. 6 


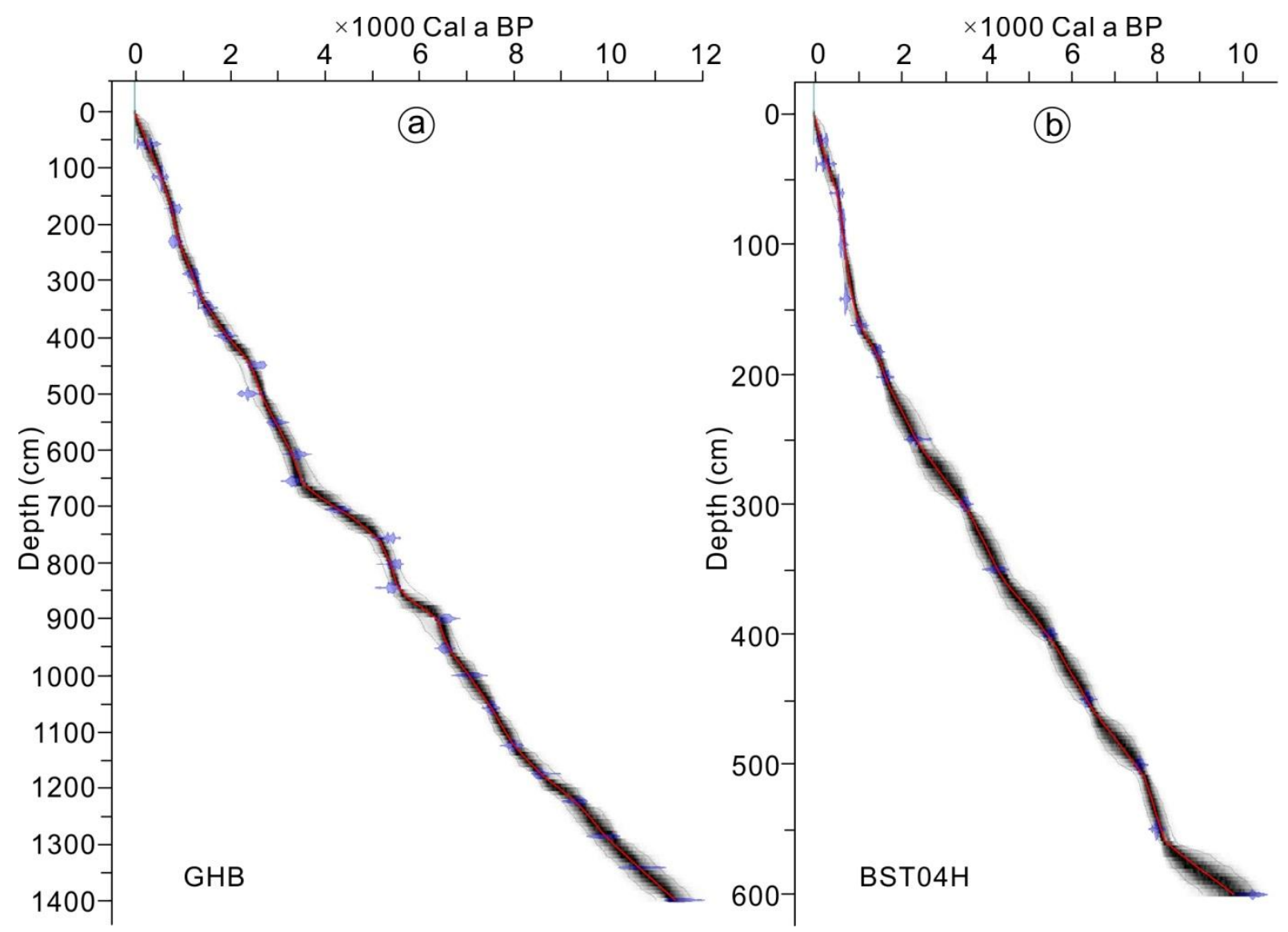

Fig. 7 

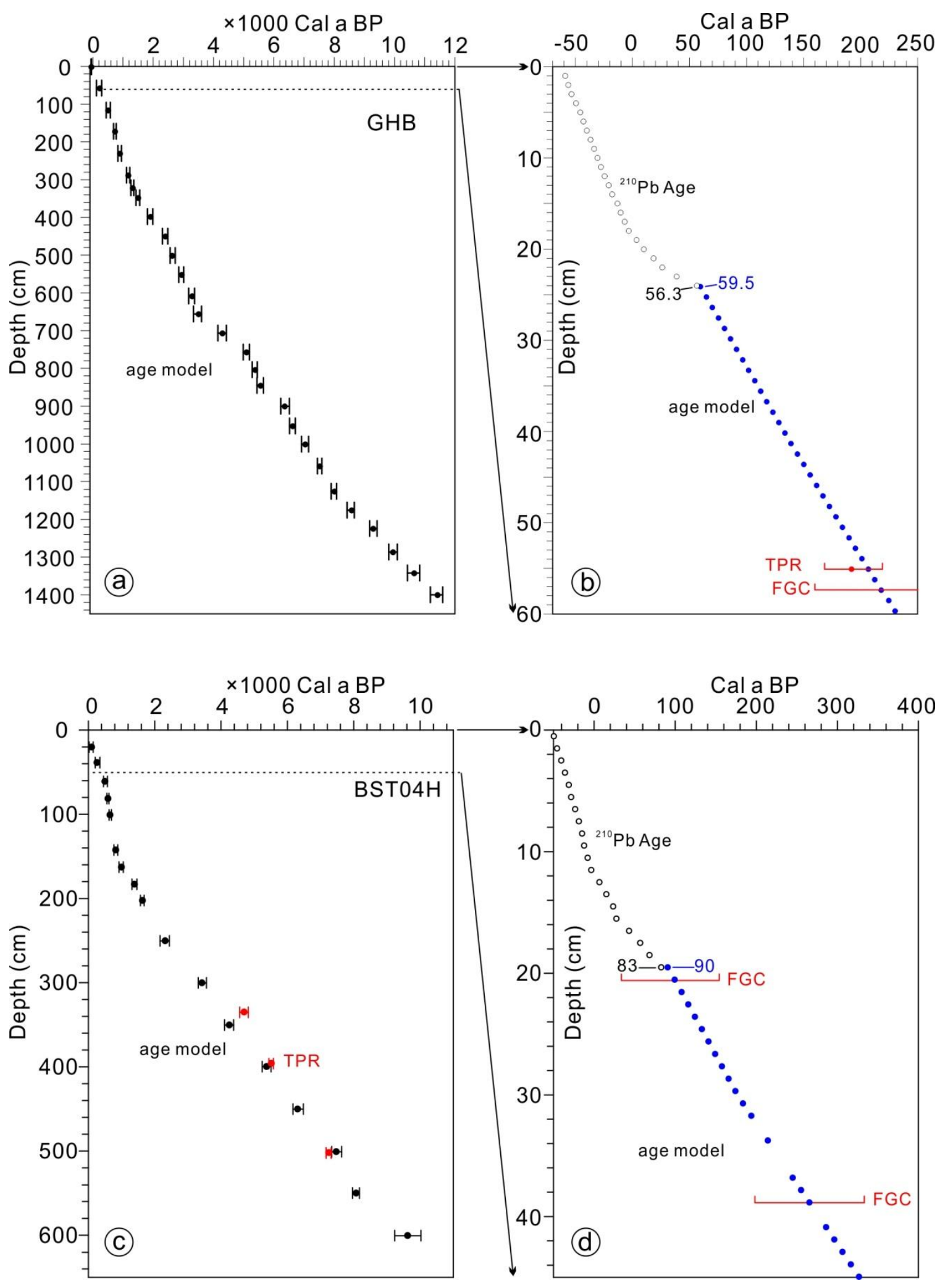

Fig. 8 


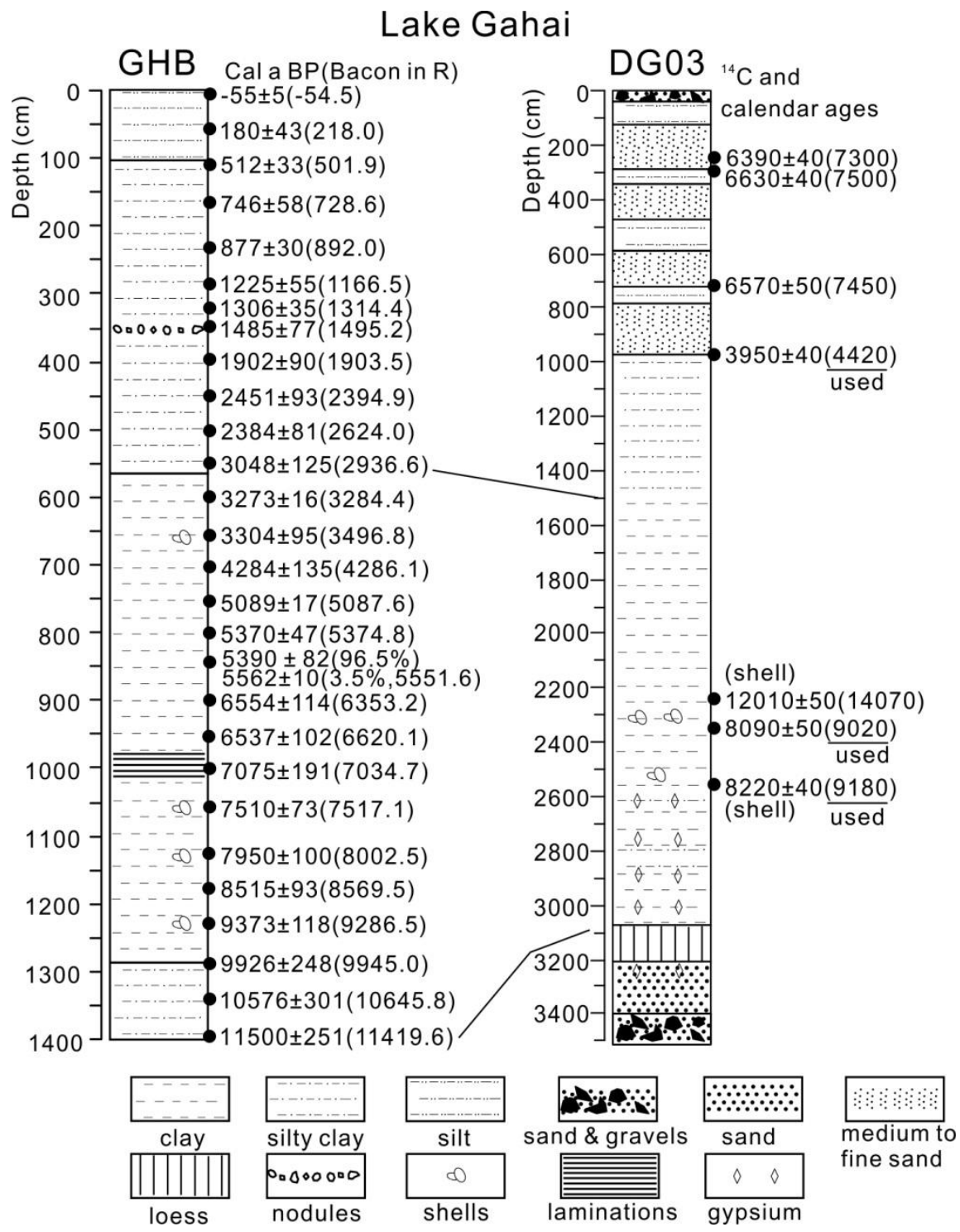

Fig. 9 


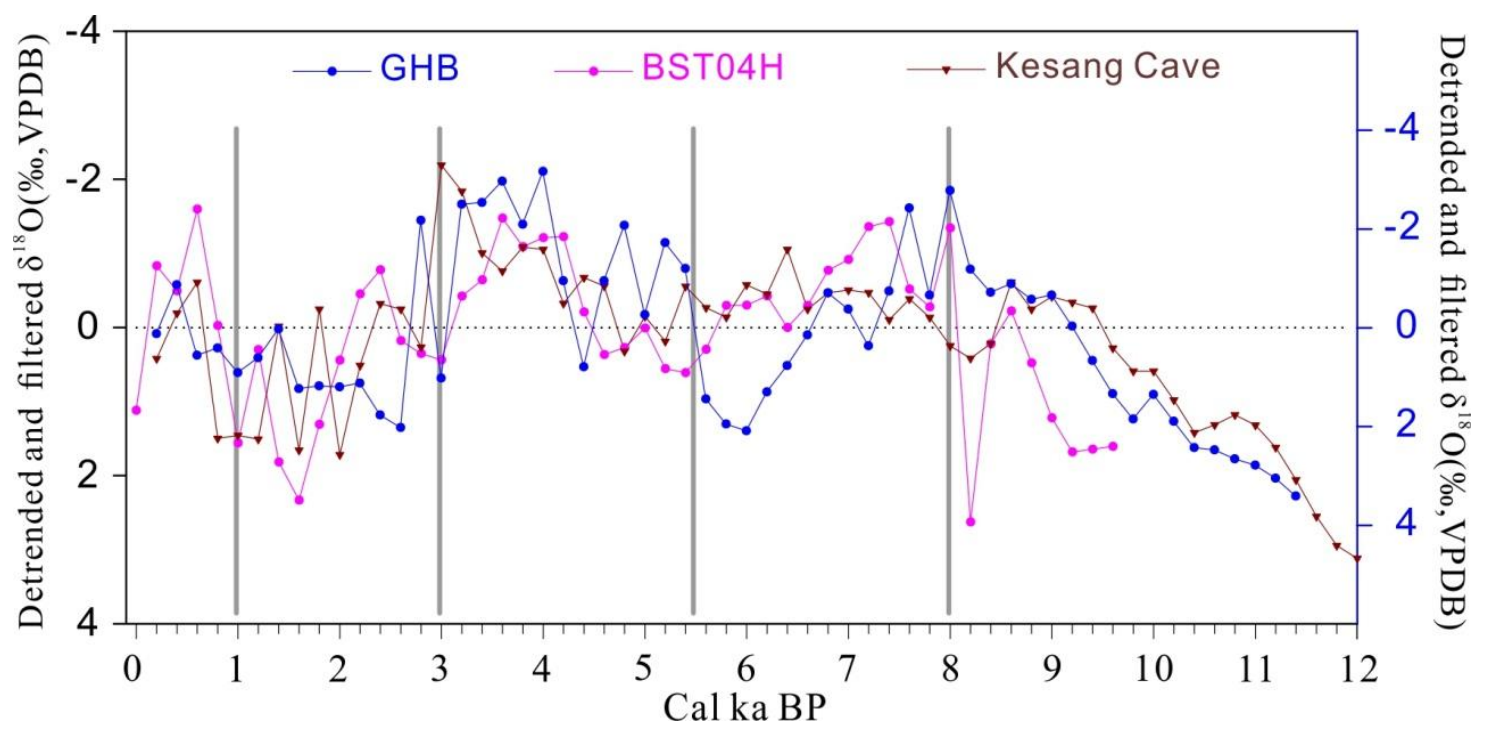

Fig. 10 
Table 1 The inorganic carbon ages of GHB and BST04H.

\begin{tabular}{|c|c|c|c|c|c|c|c|c|c|c|}
\hline Sample No & Lab Code & $\begin{array}{c}\text { Depth } \\
\text { (cm) }\end{array}$ & Material & pMC (\%) & $\delta^{13} \mathrm{C}(\%)$ & $\begin{array}{l}\text { Correct. } \\
\text { pMC }(\%)\end{array}$ & $\begin{array}{l}\text { Correct. Ages } \\
{ }^{14} \mathrm{C} \text { yr BP }\end{array}$ & $\begin{array}{l}\text { RE/old C } \\
{ }^{14} \mathrm{C} \text { yr BP }\end{array}$ & $\begin{array}{l}\text { Conv Ages } \\
{ }^{14} \mathrm{C} \text { yr BP }\end{array}$ & $\begin{array}{c}\text { Cal a BP } \\
\text { Bacon in } R\end{array}$ \\
\hline GHB01-01-001 & BA10217 & 1.15 & carbonates & 60.03 & 1.85 & 56.86 & $4536 \pm 35$ & 4522 & $-55 \pm 5$ & -54.5 \\
\hline GHB01-01-050 & Beta-298485 & 57.38 & carbonates & 39.2 & 1.39 & 37.16 & $7952 \pm 40$ & 7727 & $225 \pm 40$ & 218.0 \\
\hline GHB01-01-101 & BA10218 & 115.90 & carbonates & 45.25 & 2.41 & 42.81 & $6185 \pm 35$ & 6345 & $470 \pm 35$ & 501.9 \\
\hline GHB01-01-150 & Beta-298486 & 172.13 & carbonates & 50.2 & 2.63 & 47.47 & $5985 \pm 40$ & 5128 & $857 \pm 40$ & 728.6 \\
\hline GHB01-01-201 & BA10219 & 230.66 & carbonates & 50.13 & 2.68 & 47.40 & $5997 \pm 40$ & 5128 & $869 \pm 40$ & 892.0 \\
\hline GHB02-01-008 & Beta-298487 & 288.15 & carbonates & 47.7 & 1.8 & 45.18 & $6382 \pm 40$ & 5128 & $1254 \pm 40$ & 1166.5 \\
\hline GHB02-01-041 & Beta-325159 & 321.75 & carbonates & 50.7 & 2.35 & 47.97 & $5901 \pm 30$ & 4522 & $1379 \pm 30$ & 1314.4 \\
\hline GHB02-01-067 & BA10220 & 348.22 & carbonates & 41.85 & 2.22 & 39.61 & $7440 \pm 35$ & 5834 & $1606 \pm 35$ & 1495.2 \\
\hline GHB02-01-116 & Beta-298488 & 398.11 & carbonates & 47.3 & 2.51 & 44.74 & $6461 \pm 40$ & 4522 & $1939 \pm 40$ & 1903.5 \\
\hline GHB02-01-167 & BA10221 & 450.04 & carbonates & 41.05 & 0.81 & 38.96 & $7572 \pm 35$ & 5128 & $2444 \pm 35$ & 2394.9 \\
\hline GHB02-01-217 & Beta-298489 & 500.95 & carbonates & 41.8 & 2.51 & 39.54 & $7454 \pm 40$ & 5128 & $2326 \pm 40$ & 2624.0 \\
\hline GHB02-01-267 & BA10222 & 551.85 & carbonates & 31.67 & 1.90 & 29.99 & $9674 \pm 45$ & 6859 & $2905 \pm 45$ & 2936.6 \\
\hline GHB03-01-048 & BA10223 & 608.52 & carbonates & 25.18 & 2.16 & 23.83 & $11520 \pm 50$ & 8333 & $3187 \pm 50$ & 3284.4 \\
\hline GHB03-01-095 & BA10224 & 656.03 & carbonates & 23.57 & 2.09 & 22.31 & $12049 \pm 50$ & 8539 & use shell age & --- \\
\hline GHB03-01-095 & Beta-325155 & 656.03 & mollusk shell & 37.5 & -3.4 & 35.89 & $8231 \pm 40$ & 5128 & $3103 \pm 40$ & 3496.8 \\
\hline GHB03-01-145 & Beta-298490 & 706.57 & carbonates & 32.1 & 3.89 & 30.28 & $9597 \pm 50$ & 5731 & $3866 \pm 50$ & 4286.1 \\
\hline GHB03-01-195 & BA10225 & 757.11 & carbonates & 31.53 & 3.38 & 29.77 & $9733 \pm 40$ & 5128 & $4605 \pm 40$ & 5087.6 \\
\hline GHB03-01-241 & BA10226 & 803.61 & carbonates & 30.96 & 1.55 & 29.34 & $9850 \pm 45$ & 5128 & $4722 \pm 45$ & 5374.8 \\
\hline GHB04-01-005 & BA10227 & 845.36 & carbonates & 31.25 & 2.25 & 29.57 & $9786 \pm 40$ & 5128 & $4658 \pm 40$ & 5551.6 \\
\hline GHB04-01-056 & Beta-298491 & 900.08 & carbonates & 27.2 & 1.27 & 25.79 & $10886 \pm 50$ & 5128 & $5758 \pm 50$ & 6353.2 \\
\hline GHB04-01-105 & BA10228 & 952.64 & carbonates & 29.46 & 1.96 & 27.90 & $10256 \pm 40$ & 4522 & $5734 \pm 40$ & 6620.1 \\
\hline GHB04-01-150 & Beta-298492 & 1000.92 & carbonates & 9.8 & 0.15 & 9.31 & $19068 \pm 80$ & 12884 & $6184 \pm 80$ & 7034.7 \\
\hline GHB04-01-204 & BA10229 & 1058.85 & carbonates & 19.13 & 1.73 & 18.12 & $13720 \pm 50$ & 7301 & use shell age & --- \\
\hline GHB04-01-204 & Beta-325156 & 1058.85 & mollusk shell & 24.1 & -4.3 & 23.11 & $11768 \pm 50$ & 5128 & $6640 \pm 50$ & 7517.1 \\
\hline GHB05-01-005 & BA10230 & 1125.56 & carbonates & 15.71 & 1.39 & 14.89 & $15297 \pm 55$ & 8006 & use shell age & --- \\
\hline GHB05-01-005 & Beta-325157 & 1125.56 & mollusk shell & 22.7 & -2.7 & 21.70 & $12275 \pm 50$ & 5128 & $7147 \pm 50$ & 8002.5 \\
\hline GHB05-01-050 & BA10231 & 1175.56 & carbonates & 18.45 & 1.30 & 17.49 & $14004 \pm 50$ & 6248 & $7756 \pm 50$ & 8569.5 \\
\hline GHB05-01-094 & Beat-298493 & 1224.44 & carbonates & 8.1 & 0.91 & 7.69 & $20611 \pm 90$ & 12389 & use shell age & --- \\
\hline
\end{tabular}


Table 1 The inorganic carbon ages of GHB and BST04H (continued).

\begin{tabular}{|c|c|c|c|c|c|c|c|c|c|c|}
\hline Sample No & Lab Code & $\begin{array}{c}\text { Depth } \\
\text { (cm) }\end{array}$ & Material & pMC (\%) & $\delta^{13} \mathrm{C}(\%)$ & $\begin{array}{l}\text { Correct. } \\
\text { pMC }(\%)\end{array}$ & $\begin{array}{l}\text { Correct. Ages } \\
{ }^{14} \mathrm{C} \text { yr BP }\end{array}$ & $\begin{array}{l}\text { RE/old C } \\
{ }^{14} \text { C yr BP }\end{array}$ & $\begin{array}{c}\text { Conv. Ages } \\
{ }^{14} \mathrm{C} \mathrm{yr} \mathrm{BP}\end{array}$ & $\begin{array}{c}\text { Cal a BP } \\
\text { Bacon in } R\end{array}$ \\
\hline GHB05-01-094 & Beta-325158 & 1224.44 & mollusk shell & 19.5 & -3.1 & 18.65 & $13489 \pm 50$ & 5128 & $8361 \pm 50$ & 9286.5 \\
\hline GHB05-01-150 & BA10233 & 1286.67 & carbonates & 12.91 & 1.29 & 12.24 & $16872 \pm 65$ & 8040 & $8832 \pm 65$ & 9945.0 \\
\hline GHB05-01-200 & Beta-298494 & 1342.22 & carbonates & 9.3 & 2.37 & 8.80 & $19524 \pm 110$ & 10132 & $9392 \pm 110$ & 10645.8 \\
\hline GHB05-04-004 & BA10234 & 1400.00 & carbonates & 12.07 & 1.72 & 11.43 & $17420 \pm 70$ & 7429 & $9991 \pm 70$ & 11419.6 \\
\hline BST04H01-005 & Beta-325130 & 20.5 & carbonates & 75.4 & 0.8 & 71.6 & $2688 \pm 30$ & 2600 & $88 \pm 30$ & 99.3 \\
\hline BST04H01-023 & Beta-325131 & 38.8 & carbonates & 61.4 & 0 & 58.4 & $4325 \pm 30$ & 4105 & $220 \pm 30$ & 265.4 \\
\hline BST04H01-045 & Beta-325132 & 61.2 & carbonates & 64 & -2.4 & 61.1 & $3953 \pm 30$ & 3464 & $489 \pm 30$ & 502.7 \\
\hline BST04H01-065 & Beta-325133 & 81.6 & carbonates & 62.9 & -2.6 & 60.1 & $4089 \pm 30$ & 3464 & $625 \pm 30$ & 592.9 \\
\hline BST04H01-084 & Beta-325134 & 100.9 & carbonates & 62.3 & -4.2 & 59.7 & $4140 \pm 30$ & 3464 & $676 \pm 30$ & 655.8 \\
\hline BST04H01-105 & Beta-325135 & 122.3 & carbonates & 64.8 & -3.2 & 62.0 & $3840 \pm 30$ & --- & --- & 734.9 \\
\hline BST04H01-125 & Beta-325136 & 142.6 & carbonates & 62.3 & 0.9 & 59.1 & $4222 \pm 30$ & 3464 & $758 \pm 30$ & 824.6 \\
\hline BST04H01-145 & Beta-325137 & 163.0 & carbonates & 59.5 & -0.6 & 56.6 & $4568 \pm 30$ & 3464 & $1104 \pm 30$ & 998.0 \\
\hline BST04H01-165 & Beta-325138 & 183.3 & carbonates & 56.5 & 0.9 & 53.6 & $5007 \pm 30$ & 3464 & $1543 \pm 30$ & 1392.2 \\
\hline BST04H01-184 & Beta-325139 & 202.7 & carbonates & 50.9 & 1.6 & 48.2 & $5857 \pm 30$ & 4151 & $1706 \pm 30$ & 1633.7 \\
\hline BST04H01-231 & Beta-325140 & 250.5 & carbonates & 35.7 & -0.8 & 34.0 & $8668 \pm 40$ & 6358 & $2310 \pm 40$ & 2318.6 \\
\hline BST04H01-280 & Beta-325141 & 300.3 & carbonates & 45.5 & -0.2 & 43.3 & $6729 \pm 30$ & 3464 & $3265 \pm 30$ & 3426.4 \\
\hline BST04H02-068 & Beta-325142 & 350.6 & carbonates & 28.4 & -1.4 & 27.1 & $10496 \pm 50$ & 6673 & $3823 \pm 50$ & 4248.8 \\
\hline BST04H02-110 & Beta-325143 & 399.9 & carbonates & 37.9 & 1.1 & 35.9 & $8218 \pm 40$ & 3464 & $4754 \pm 40$ & 5382.2 \\
\hline BST04H02-153 & Beta-325144 & 450.4 & carbonates & 34.2 & -0.1 & 32.5 & $9024 \pm 40$ & 3464 & $5560 \pm 40$ & 6308.1 \\
\hline BST04H02-196 & Beta-325145 & 500.9 & carbonates & 27.1 & 0 & 25.8 & $10895 \pm 40$ & 4169 & $6726 \pm 40$ & 7473.1 \\
\hline BST04H02-238 & Beta-325146 & 550.2 & carbonates & 31.2 & -0.5 & 29.7 & $9755 \pm 40$ & 2600 & $7155 \pm 40$ & 8074.3 \\
\hline BST04H03-057 & Beta-325147 & 600.6 & carbonates & 14.9 & -5.9 & 14.3 & $15605 \pm 60$ & 6534 & $9071 \pm 60$ & 9622.2 \\
\hline GHB01-01-048 & Beta-325149 & 55.08 & TPR & 98 & -24.2 & 97.84 & $160 \pm 30$ & --- & $175 \pm 30$ & $192 \pm 25$ \\
\hline BST04H & LAMS05097 & 335 & TPR & --- & --- & --- & $4105 \pm 40$ & --- & $4105 \pm 40$ & $4698 \pm 130$ \\
\hline BST04H & LAMS05098 & 396 & TPR & --- & --- & --- & $4740 \pm 40$ & --- & $4740 \pm 40$ & $5516 \pm 70$ \\
\hline BST04H & KIA25466 & 502 & TPR & --- & --- & --- & $6337 \pm 28$ & --- & $6337 \pm 28$ & $7247 \pm 76$ \\
\hline
\end{tabular}


Table 2 Radiocarbon dating of water DIC and paleolake sediments exposed in the catchment.

\begin{tabular}{|c|c|c|c|c|c|}
\hline $\begin{array}{c}\text { Sample } \\
\text { ID } \\
\end{array}$ & Location & $\begin{array}{l}\mathrm{HCO}_{3}^{-} \\
\left(\mathrm{mg}^{-} \mathrm{L}^{-1}\right)\end{array}$ & $\begin{array}{l}\mathrm{CO}_{3}{ }^{2-} \\
\left(\mathrm{mg} \cdot \mathrm{L}^{-1}\right)\end{array}$ & $\begin{array}{l}\text { Conductivity } \\
\left(\mu \mathrm{S} \cdot \mathrm{cm}^{-1}\right)\end{array}$ & $\begin{array}{l}{ }^{14} \text { C Age } \\
\text { (yr BP) }\end{array}$ \\
\hline \multicolumn{6}{|c|}{ Water DIC } \\
\hline BYHCD & $37^{\circ} 18^{\prime} 48^{\prime \prime} \mathrm{N} ; 97^{\circ} 22^{\prime} 07^{\prime \prime} \mathrm{E}$ & 150.4 & 0 & 408 & $2140 \pm 30$ \\
\hline HL02 & $37^{\circ} 17^{\prime} 34^{\prime \prime} \mathrm{E} ; 96^{\circ} 53^{\prime} 43^{\prime \prime} \mathrm{N}$ & 48.69 & 85.04 & 1224 & $1190 \pm 30$ \\
\hline HL01 & $37^{\circ} 14^{\prime} 23^{\prime \prime} \mathrm{N} ; 96^{\circ} 50^{\prime} 32^{\prime \prime} \mathrm{E}$ & 24.97 & 159.29 & 1448 & $1060 \pm 30$ \\
\hline TSN01 & $37^{\circ} 09^{\prime} 16^{\prime \prime} \mathrm{N} ; 96^{\circ} 59^{\prime} 22^{\prime \prime} \mathrm{E}$ & 407.61 & 764.70 & 40924 & $102.3 \pm 0.5 \mathrm{pMC}$ \\
\hline NGH01 & $37^{\circ} 08^{\prime} 33^{\prime \prime} \mathrm{N} ; 97^{\circ} 31^{\prime} 06^{\prime \prime} \mathrm{E}$ & 162.67 & 0 & 324 & $5620 \pm 30$ \\
\hline GHCW2 & $37^{\circ} 07^{\prime} 35^{\prime \prime} \mathrm{N} ; 97^{\circ} 31^{\prime} 48^{\prime \prime} \mathrm{E}$ & --- & --- & --- & $1550 \pm 30$ \\
\hline GH012 & $37^{\circ} 09^{\prime} 23^{\prime \prime} \mathrm{N} ; 9^{\circ} 32^{\prime} 27^{\prime \prime} \mathrm{E}$ & 154.61 & 184.52 & 101630 & $360 \pm 30$ \\
\hline GH08 & $37^{\circ} 08^{\prime} 30^{\prime \prime} \mathrm{N} ; 9^{\circ} 33^{\prime} 25^{\prime \prime} \mathrm{E}$ & 124.36 & 304.12 & 99760 & $270 \pm 40$ \\
\hline GH03 & $37^{\circ} 06^{\prime} 54^{\prime \prime} \mathrm{N} ; 97^{\circ} 34^{\prime} 35^{\prime \prime} \mathrm{E}$ & 87.39 & 203.07 & 98282 & $240 \pm 30$ \\
\hline EGH01 & $37^{\circ} 08^{\prime} 49^{\prime \prime} \mathrm{N} ; 97^{\circ} 34^{\prime} 08^{\prime \prime} \mathrm{E}$ & 352.97 & 9.057 & --- & $100 \pm 30$ \\
\hline EGH02 & $37^{\circ} 08^{\prime} 41^{\prime \prime} \mathrm{N} ; 97^{\circ} 34^{\prime} 11^{\prime \prime} \mathrm{E}$ & --- & --- & --- & $600 \pm 30$ \\
\hline WGH02 & $37^{\circ} 06^{\prime} 34^{\prime \prime} \mathrm{N} ; 97^{\circ} 31^{\prime} 33^{\prime \prime} \mathrm{E}$ & 426.63 & 0 & 690 & $6280 \pm 30$ \\
\hline \multicolumn{6}{|c|}{ Paleolake Sediments } \\
\hline NGH03 & $37^{\circ} 08^{\prime} 39^{\prime \prime} \mathrm{N} ; 97^{\circ} 30^{\prime} 59^{\prime \prime} \mathrm{E}$ & --- & --- & --- & $14550 \pm 50$ \\
\hline NGH04 & $37^{\circ} 08^{\prime} 34^{\prime \prime} \mathrm{N} ; 97^{\circ} 30^{\prime} 51^{\prime \prime} \mathrm{E}$ & --- & --- & --- & $16660 \pm 60$ \\
\hline NGH05 & $37^{\circ} 08^{\prime} 29^{\prime \prime} \mathrm{N} ; 9^{\circ} 30^{\prime} 38^{\prime \prime} \mathrm{E}$ & --- & --- & --- & $16690 \pm 60$ \\
\hline
\end{tabular}


Figure Captions

Fig. 1. Locations of Lake Gahai and Lake Bosten (a) and the core sites of GHB (b) and BST04H (c). The dash blue line in (a) roughly represents the modern summer monsoon limit. The red dot in (a) shows the location of Kesang Cave (Cheng et al., 2012) which is mentioned in the text. The isobaths of both lakes are also shown in (b) and (c). The black arrows in (c) show the locations of input river mouth and the outlet of Lake Bosten.

Fig. 2. Lithology of GHB and BST04H and depths where fine-grained carbonate (FGC) samples were dated. Depths where there are shells in GHB and terrestrial plant remains (TPR) previously dated in BST04H (Huang et al., 2009) are also shown.

Fig. 3. Locations and ages of modern water DIC and exposed paleolake sediments in the catchment of Lake Gahai. The black triangle shows the location of GHB core in Lake Gahai. The black arrows show the flowing direction of the Bayin River.

Fig. 4. Preliminary age-depth relationships of cores GHB from Lake Gahai (a) and BST04H from Lake Bosten (b) with the range of $95 \%$ confidence. Each type of symbols is listed in the legend box below the figure.

Fig. 5. Refined regressions for ages of GHB form Lake Gahai (a) and BST04H from Lake Bosten (b). Each type of symbols is listed in the legend box below the figure.

Fig. 6. Ages contributed by detrital carbonates and their relationship with the carbonate content of the dated samples (a) and the relationship of detrital ages with their proportions (b). The scale and unit of the vertical axis of (b) is the same as that of (a).

Fig. 7. Calibration results of the radiocarbon ages with Bacon in R for GHB from Lake Gahai (a) and BST04H from Lake Bosten (b). The red line within the shaded area is the age model, namely the weighted mean (wmean) values of each depth provided by Bacon.

Fig. 8. Comparison of calendar ages based on inorganic carbon dating of both cores and the ${ }^{210} \mathrm{~Pb}$ and $\mathrm{TPR}$ ages. (a) and (b) are results of GHB from Lake Gahai; (c) and (d) are results from BST04H in Lake Bosten. FGC $=$ fine-grained carbonates .

Fig. 9. Comparison of the lithology and dating results from GHB core (water depth of $11.4 \mathrm{~m}$ in the lake, Fig. 1b) and DG03 core on the northern shore of Lake Gahai, which was estimated to be Holocene sediments but failed in establishing a reliable chronology (Chen et al. 2007; Cao et al. 2009; Pan and Chen, 2010; He et al., 2014).

Fig. 10. Comparison of the detrended and filtered carbonate $\delta^{18} \mathrm{O}$ at $200-\mathrm{yr}$ resolution from Gahai and Bosten with that of the speleothem record from Kesang Cave (Cheng et al., 2012) for testing the chronologies. Four vertical grey lines show the major shifting points during the Holocene. 
Developing inorganic carbon-based radiocarbon chronologies for lake sedimens in arid NW China

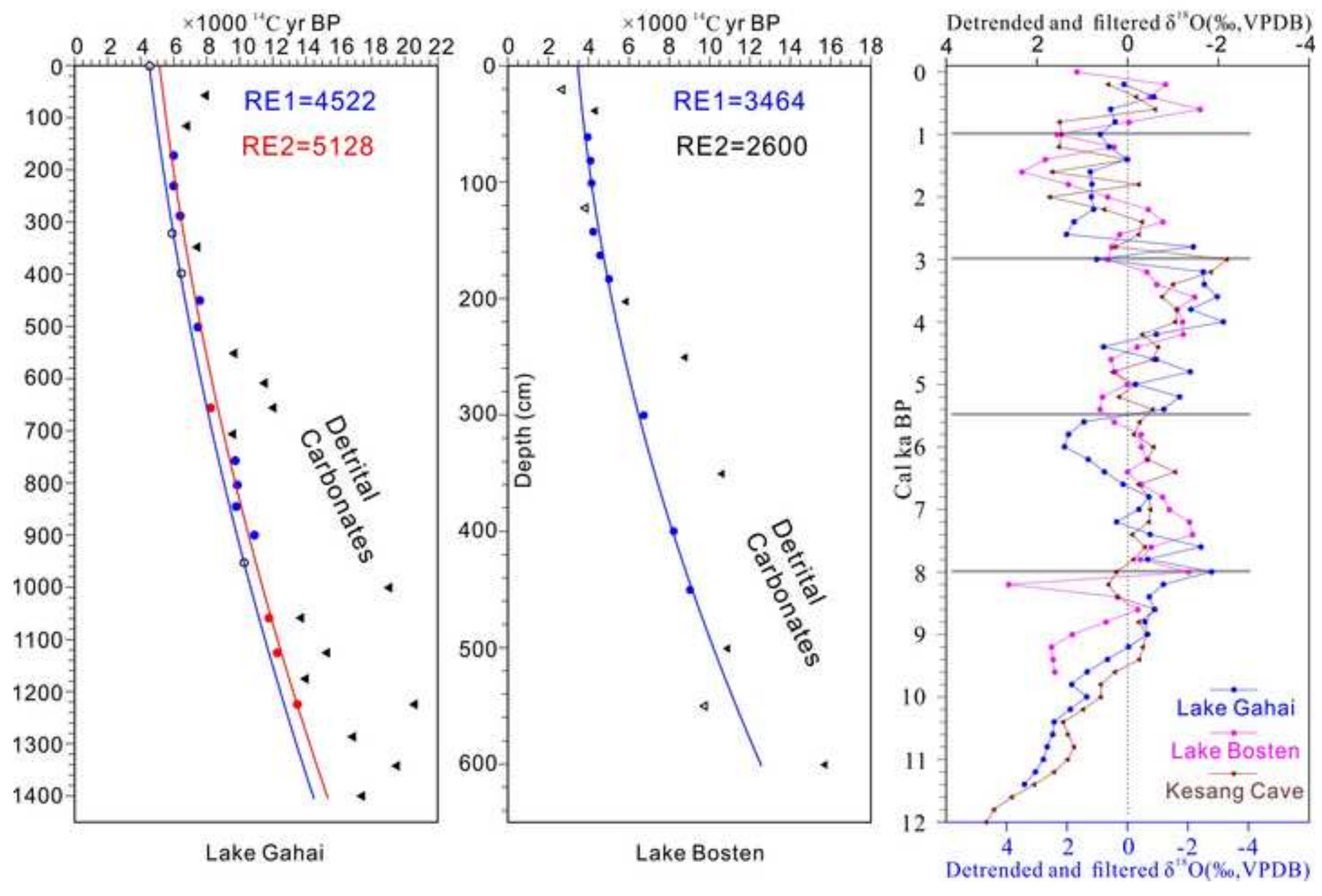

